NBER WORKING PAPER SERIES

\title{
QUARTERLY DATA ON THE CATEGORIES AND CAUSES OF BANK DISTRESS DURING THE GREAT DEPRESSION
}

\author{
Gary Richardson \\ Working Paper 12715 \\ http://www.nber.org/papers/w12715 \\ NATIONAL BUREAU OF ECONOMIC RESEARCH \\ 1050 Massachusetts Avenue \\ Cambridge, MA 02138 \\ December 2006
}

I thank Shagufta Ahmed, Shaista Ahmed, Jacqueline Chattopadhay, Ching-Yi Chung, Nathan Montgomery, Yuiichi Inomata, Mark Ng, Mitra Pai, Doris Sum, Brandon Tsang, Ian Wagner, and Eve Wang for research assistance. I thank Reid Click, Deborah Kauffman, Ed and Edwin Richardson, and Gloria Richardson for accommodations near the National Archives. I thank Erik Heitfield for the loan of photographic equipment. I thank Marigee Bacolod, Dan Bogart, William Branch, Mark Carlson, Milton Friedman, Michelle Garfinkel, Joseph Mason, Kris Mitchener, and Elmus Wicker for comments on earlier drafts of this essay. I thank numerous friends and colleagues for comments, advice, and encouragement. Portions of this research was funded by NSF Grant D/SES-0551232. The views expressed herein are those of the author(s) and do not necessarily reflect the views of the National Bureau of Economic Research.

(C) 2006 by Gary Richardson. All rights reserved. Short sections of text, not to exceed two paragraphs, may be quoted without explicit permission provided that full credit, including $\odot$ notice, is given to the source. 
Quarterly Data on the Categories and Causes of Bank Distress During the Great Depression Gary Richardson

NBER Working Paper No. 12715

December 2006

JEL No. E0,E4,E44,N1,N12,N2

\section{ABSTRACT}

During the contraction from 1929 through 1933, the Federal Reserve System tracked changes in the status of all banks operating in the United States and determined the cause of each bank suspension. This essay introduces quarterly series derived from that hitherto dormant data and presents aggregate series constructed from it. The new data series will supplement, and in some cases, supplant the data currently used to study banking panics of the Great Depression, which was published by the Federal Reserve Board of Governors in 1937.

Gary Richardson

Department of Economics

University of California, Irvine

Irvine, CA 92697-5100

and NBER

garyr@uci.edu 


\section{Introduction}

The causes, consequences, and possibilities of preventing the banking panics of the Great Contraction have been debated for seven decades. The debate's factual foundations rest upon data published in the Federal Reserve Bulletin. The September 1937 issue contains the only comprehensive collection of statistics on suspended banks, and is the sole source of aggregate bank failure rates (Board of Governors 1937, hereafter FRB'37). ${ }^{1}$ Scholars studying the contraction continuously redefine, reinterpret, and reveal new relationships between data from FRB'37 and measures of industrial, commercial, and financial activity.

The principal reason the debate continues may be the primary source of evidence. FRB'37 provides imperfect information about bank distress. It distinguishes neither temporary from terminal suspensions, nor voluntary from involuntary liquidations, nor institutions afflicted by illiquidity from banks suffering insolvency. It contains information neither on the causes of bank suspensions nor the number of bank mergers. The smallest period of aggregation at the national level is the month and at the Federal Reserve district level is the year. Key terms remain undefined, leaving much open to interpretation.

This essay introduces new statistical series that provide precise, detailed, aggregate information about categories of bank distress and causes of bank suspensions. The source for the new series is the same as for the old series. ${ }^{2}$ From 1929 though 1933, the Board of Governors

1 Reprints of these series (or cross-tabulations based upon them) appeared in Banking and Monetary Statistics (Board of Governors 1943) and Historical Statistics of the United States (Bureau of Census 1975). Precursors to these series appeared in various publications of the Board of Governors and in Bank Suspension in the United States (Goldenweiser et. al. 1931). Studies of the banking panics published prior to 1938 employ these predecessor series.

2 The St. 6386 forms were the basis of the Federal Reserve's bank data collection system from 1929 to 1933. All facts and figures about bank distress published by the Board of Governors or the Federal Reserve district banks and much of the material published by state banking authorities originated with this source. 
collected data on changes of status for all banks operating in the United States, both members of the Federal Reserve System and nonmembers, state and national, incorporated and private. The Board also analyzed the cause of each bank suspension. The Division of Bank Operations recorded this information on the St. 6386 series of forms. Form St. 6386a reported bank consolidates. Form St. $6386 b$ reported bank suspensions. Form St. 6386c reported all other bank changes. ${ }^{3}$ Facsimiles of the forms appear in the appendix.

The St 6386 series comprehensively covered the commercial banking industry from January 1929 through the national banking holiday in March 1933. Observations existed for a wide array of events affecting banks. These events included the major, such as openings, closings, reopenings, receiverships, and consolidations, and the minor, such as changes in Federal Reserve membership, capital stock, charter type, and even street address. The forms also included financial information for each bank on the date of each transaction. The complete series of St. 6386 forms survives in the National Archives of the United States.

The remainder of this essay introduces this recently rediscovered source. Section 1 reviews the relevant literature, highlights FRB'37's role in academic debates, discusses how the extant evidence shapes academic opinions about the contraction, and elucidates the utility of the archival evidence. Section 2 describes the data, defines key concepts, and discusses issues important for interpreting empirical work based upon this source. Section 3 describes the original sources of information and the procedures that the Federal Reserve used to validate and crosscheck the evidence. The purpose of the extended discussion is to reassure the reader of the

3 The surviving forms may be found in the National Archives, Record Group 82, Federal Reserve Central Subject File, file number 434.-1, "Bank Changes 1921-1954 Districts 1929-1954 - Consolidations, Suspensions and Organizations-St. 6386 a,b,c, (By States) 1930-1933.” The forms are filed alphabetically by state, name of town or city, and name of bank. Multiple entries for individual banks appear in chronological order. To avoid repeated, lengthy citations in the body of the essay and this appendix, after quotations from the archival data, the information required to locate the form (i.e. name of state, town, bank) is indicated in brackets. 
veracity of the Federal Reserve's observations. Section 4 compares the archival data to the extant aggregate series and to studies based on microeconomic evidence. The comparisons show that aggregate series constructed from the archival data match equivalent series published in FRB'37 and that the Division of Bank Operation's conclusions about the causes of suspensions match those of modern scholars using historical and econometric methods. Section 5 presents new quarterly series on the categories and causes of bank distress. The new series supplement the FRB'37 series most often used by to study the contraction. Section 6 discusses potential uses of the new data.

\section{Review of the Literature}

Scholars have long studied the banking crises of the Great Contraction. The initial studies analyzed data from FRB'37 aggregated at the national level. Later studies scrutinized FRB'37 data aggregated at lower levels. Recent studies combine data from FRB'37 with data drawn from the balance sheets of national and Federal Reserve member banks. This section reveals correlations between the sources that scholars have analyzed and the conclusions that scholars have reached.

Scholars ask three general questions about the banking system during the contraction of the early 1930s. Why did bank suspensions surge at certain points in time? How did bank suspensions affect commercial and industrial activity? Could Federal Reserve intervention have prevented (or did its actions trigger) this crisis? Despite 70 years of analysis, debate persists about the answer to each inquiry.

Concerning the reasons that banks failed, some scholars conclude that a contagion of fear, a flight to cash holdings, and withdrawals en masse drained deposits from banks and pushed financial markets towards collapse. Illiquidity of assets and Federal Reserve inaction exacerbated 
the credit crunch. Milton Friedman and Anna Schwartz (1963) argue that the Federal Reserves' failure to act as a lender of last resort, prevent banking panics, and stem the decline of the money supply transmogrified what would have been an ordinary recession into the Great Depression by examining seasonally-adjusted series of deposits in suspended banks from FRB'37 to determine the dates of banking panics and correlating those dates with changes in monetary aggregates. Elmus Wicker (1996) uses district-level data on suspensions from FRB'37 to illuminate the regional patterns of panics.

Other scholars conclude that banks failed because the economy contracted. Loan default rates rose. Asset values declined. Deteriorating fundamentals forced banks into insolvency, continuing a process of liquidation that began during the 1920s. Peter Temin (1976) argue that real, rather than monetary, forces caused banks to fail and the economy to contract by regressing state-level FRB'37 suspension data on various explanatory variables. Charles Calomiris and Joseph Mason (2003) support the supposition that contagion forced banks to fail by regressing time-to-liquidation for individual Fed member banks on an array of bank characteristics, aggregate variables, and state-level FRB'37 suspension rates. Eugene N. White (1984) initiated the use of bank balance sheet data to analyze these issues. His seminal work employed a sample of national banks. He regressed their fates (survival or liquidation) on their financial characteristics and aggregate variables. ${ }^{4}$

Concerning the consequences of the banking crises, some scholars believe that banking panics had monetary effects. Panics eroded depositors' confidence, induced further withdrawals,

4 Eugene White (1984) pioneered efforts to examine samples of data from national banks. Subsequent work examines banks within individual cities, states, and Federal Reserve districts (Charles Calomris and Joseph Mason 1997, Mark Carlson 2004). The most recent and comprehensive work (Calomiris and Mason 2003), which analyzes a panel of all Federal Reserve member banks, yields a strong and stark conclusion. The "two Friedman-Schwartz crises are not associated with positive unexplained residual failure risk, or increased importance of bank illiquidity for forecasting failure (2003)." 
forced banks to liquidate assets at deep discounts, lowered asset prices, encouraged banks to hold excess reserves, and reduced the money multiplier. This vicious cycle reduced the money supply and turned what would have been a typical recession into a cataclysmic contraction. Friedman and Schwartz (1963) contains the seminal statement of the monetarist position, whose roots date back at least to the publications of Lauchlin Curry (1931 and 1932) and the Chicago monetary tradition which arose at that time. Friedman and Schwartz employed data from FRB'37. The early monetarists did not have access to this data. Instead, they used data drawn from earlier editions of the Federal Reserve Bulletin.

Other scholars see bank failures as symptoms of ongoing events with no special role in the propagation of the downturn. This view arises from Keynesian, classical, real business cycle, and other macroeconomic models. Temin's spending hypothesis (Temin 1976) is the seminal statement of the stark Keynesian conception of the contraction, which sees bank failures as a symptom of the autonomous decline in consumption and investment expenditure, and which dates back at least to the publication of Keynes' General Theory.

Another set of scholars maintains that bank panics influenced economic activity by disrupting financial intermediation. Bank failures increased the cost of credit intermediation, dislocated the financing of small and medium firms, disrupted current production, and curtailed investment spending. This financial acceleration deepened the depression. In the seminal articles in this line of research, Ben Bernanke (1982) regresses growth rates of industrial production on first differences of deposits in suspended banks (drawn from FRB'37) to show that suspensions increased the cost of credit intermediation.

Concerning the possibilities of preventing the banking panics, some scholars argue the Federal Reserve could have done little to aid ailing banks. Fundamental forces pushed banks into 
insolvency; monetary intervention could not pull them out. Liquidity assistance could not eliminate loan losses. Open-market expansion - even on a massive scale - could not lift the economy out of the liquidity trap (Temin 1976).

Other scholars argue that the Federal Reserve could not aid ailing banks directly, since illiquidity and contagion caused few banks failures, but that massive open-market expansions, such as those that the Roosevelt administration implemented after abandoning the gold standard, could reignite economic progress, and thus indirectly alleviate the banking situation (Calomiris and Mason 2003, Eichengreen 1992, Romer 1992, Temin 1989).

Another set of scholars argue that even limited assistance from the Federal Reserve might have mitigated banking panics. By acting as a lender of last resort and extending loans to solvent but illiquid institutions, the Federal Reserve could have kept ailing institutions afloat. A credible commitment to do so might have calmed consumers, reassured bankers, raised the money multiplier, alleviated the credit crunch, and eased the economic situation (Richardson and Troost 2005).

A final and influential set of scholars concludes that the Federal Reserve's sins were of commission as well as omission. The Federal Reserve not only neglected to aid ailing banks, but by raising interest rates, reducing the monetary base, and restricting discount lending, the Federal Reserve weakened all banks, and created conditions conducive to panics. As evidence, these scholars highlight the Federal Reserve's monetary contraction in 1928 and the Federal Reserve's defense of the gold standard in 1931 (Friedman and Schwartz 1963, Meltzer 2003).

The policy views of all of these schools of thought stem from their views on the causes of the banking crisis. Scholars who think that banks failed because they lacked liquidity believe that the Federal Reserve could have alleviated the situation by acting as a lender of last resort. 
Scholars who think that banks failed because the economy contracted and borrowers defaulted believe that the Federal Reserve could not have saved the situation by acting as a lender of last resort, but might have aided the banks indirectly by reinflating the economy. As I noted previously, these beliefs arise largely from the data which the scholars examine. The debate about policy, therefore, indirectly reflects the use of data sources.

A correlation exists between the sources that scholars utilize and the conclusions that scholars reach. Scholars who study aggregate data tend to view illiquidity and the withdrawal of deposits as the root cause of the banking crisis. Scholars who study micro data tend to view insolvency and the declining value of investment portfolios as the root of the crisis. The correlation exists for two reasons. First, different sources illuminate different dimensions of the banking industry and highlight different points in time and space, leading to different interpretations of events. Each source portrays a portion of a complex, dynamic mosaic. None portrays the entire picture. Second, the extant sources share several weaknesses. All of the sources provide imperfect information about changes in banks' status. They distinguish neither temporary from terminal suspensions, nor voluntary from involuntary liquidations, nor institutions afflicted by illiquidity from banks suffering insolvency. They describe neither on the causes of bank suspensions nor the number of bank mergers. They neglect consolidations of banks in financial difficulties and seeking to avoid suspension. Unclear and inconsistent terminology leaves much of the information in the sources subject to interpretation. Reconciling scholars' views requires comprehensive, definitive data. The remainder of this essay turns to that task.

\section{Section 2: Data Origins and Definitions}

This section discusses the data on bank distress collected by the Federal Reserve Board of 
Governors during the early 1930s. The discussion emphasizes the methods that Federal Reserve agents employed to ascertain the causes of bank suspensions and the lexicon that the Board of Governors devised during the 1920 s to facilitate their analysis. The discussion cites the memos and training materials distributed to Federal Reserve employees undertaking this task and outlines the algorithms that they employed when analyzing the evidence.

During the 1920s, the Federal Reserve Board of Governors embarked on an ambitious project: the creation of standard statistical reports for all banks operating in the United States, both members of the Federal Reserve System and nonmembers, national and state, incorporated and private. In August 1925, the Board began collecting information on the causes of bank suspensions. The Division of Bank Operations introduced Form X-4401, "Notification of Bank Suspension or Insolvency," and Form X-4402, "Notification of Termination of Insolvency or Suspension." The forms remained in use for four years.

During that period, the Board of Governors strove to improve the accuracy of the information that they collected. The process was interactive and ongoing. The Board circulated forms to agents around the country and asked them to suggest improvements. They solicited comments from bureaucrats, bankers, examiners, and academics. They amended the forms to make them more concise and complete. Correspondence between the Board of Governors and the Federal Reserve district banks announced up-and-coming modifications and important decisions concerning the coding of ambiguous cases. A series of memos defined key terms and explained how to fill out the forms.

Analysts strove to standardize the definitions of the words with which they worked. Standardization was important, because definitions of banking terms varied across time and jurisdictions. Each state-banking bureau published its own report and used terms as it saw fit. 
Explicit definitions seldom appeared. This lexical ambiguity caused confusion. Multiple definitions existed for frequently used terms. Many varied according to context. For example, the nine letters l-i-q-u-i-d-a-t-e referred in some circumstances to the sale of assets, in other circumstances to a change in a corporate charter, and at other times to the dissolution of a financial institution and its departure from the banking business. At the end of the 1920s, as the Federal Reserves' lexicon approached its final form and its research staff assimilated the lessons that they had learned, the Board of Governors authorized a comprehensive revision of the panoply of forms used to gather information on the status of banks.

In 1929, the Board of Governors introduced the documents devised via that endeavor: the St. 6386 series of forms. Form St. 6386a reported bank consolidations. The Federal Reserve defined consolidation in a de facto rather than de jure sense.

A consolidation is the corporate union of two or more ongoing banks into one bank which continues under a single charter, either new or old. The term is used not in a legal or technical sense, but in an economic sense, the essential feature being that the business of two or more going banks becomes concentrated under one charter and one management. The method of effecting the consolidation, whether by purchase of assets, assumption of deposit liabilities, exchange of stock, or other procedure, varies with circumstances and is unessential for the present purpose. What is here described as a consolidation is frequently designated by the terms "merger," "absorption," "amalgamation," "combination," or "purchase," according to different points of view. It includes those cases where one bank absorbs another and turns it into a branch. It also includes those cases where a given bank is absorbed by two or more banks, which distribute its business among themselves. A consolidation is not a simple transaction like a conversion, a liquidation, a primary organization, etc., but is inevitable complicated by the fact that these other transactions are incidental to it. That is, a consolidation as often as not entails a voluntary liquidation and the issuance of a new charter; but these attendant circumstances should not obscure the important fact that a concentration of banking has been effected by the transaction as a whole (Goldenweiser et. al. 1931, pp. 87-88).

Form St. 6386a recorded these transactions and the attendant circumstances. Details included the name of the absorbing bank, the fate of offices and charter of the bank being absorbed, and 
whether the banks consolidated because they faced financial difficulties or in order to avoid suspension.

The latter information helped distinguish between the categories of consolidation and suspension. The distinction involved several simple rules. First, a bank that merged with another bank was classified as a consolidation if it was "not at any time closed to depositors, even though the reason for the consolidation or succession may have been financial difficulties encountered by the bank (Federal Reserve memo, November 18, 1929)." Second, a transaction was classified as a consolidation if the assets and liabilities of a weak bank were transferred to another bank, and then, the denuded bank suspended and surrendered its charter (Goldenweiser et. al. 1931, p. 88). Third, a transaction was classified as a terminal bank suspension if at the time of absorption or merger the bank had been closed for at least one business day.

Form St. 6386b reported bank suspensions. According to the Federal Reserve's financial lexicon, a bank suspension occurred when payments were halted

to the public either temporarily or permanently by supervisory authorities or by the bank's board of directors on account of financial difficulties, regardless of whether or not the bank is ultimately classed as a suspension by the supervisory authorities (Federal Reserve memo, November 18, 1929)

and regardless of whether or not the depositors ultimately suffered losses. A suspension had to last overnight. A bank that closed its doors in the morning and reopened them in the afternoon did not fit into the classification. A suspension had to include the cessation of normal banking business. A bank that slowed withdrawals by holding depositors to the agreements that they signed when opening accounts and requiring them to provide 30,60 , or 90 days notice of savings withdrawals did not fit into the classification. A bank which, without actually closing, obtained agreements from depositors to waive a portion of their deposits or to defer the withdrawal of a portion of their deposits was not classified as a suspension. A bank that closed during a special 
holiday declared by civil authorities and remained closed only during such holiday or part thereof was not classified as a suspension.

Form St. 6386c reported changes in the status of financial institutions, including voluntary liquidations and the reopening of suspended banks. A voluntary liquidation occurred when a bank's directors paid off all depositors and creditors in full, sold the remaining assets, distributed proceeds to stockholders, annulled the bank's charter, and abandoned the banking business. Some voluntary liquidations were orderly affairs arranged months in advance. Others resembled suspensions. A sudden shock, such as the death of the founder, forced a bank to close its doors, and the discouraged board of directors decided to repay depositors rather than attempt to reopen the institution. The latter case was classified as a voluntary liquidation, rather than a suspension, as long as the winding up of the bank's business did not require the intervention of regulators or courts, and as long as the owners of the bank could repay all creditors the full value of their claims.

A reopening occurred when a suspended bank resumed operations. A bank could resume operations voluntarily at any time until regulators used legal powers to take authority over the institution or the courts appointed a receiver to liquidate the bank. After either event, a bank could reopen only with the consent of judicial authorities. In certain circumstances, reopening also required the agreement of creditors such as depositors and stockholders. In many cases, reopenings entailed the reorganization of affairs. Depositors waived rights to portions of their deposits. Stockholders waived their original capital and paid assessments of up to $100 \%$ of the value of their stock. In most cases, these reorganizations appear to have been voluntary agreements among the interested parties, facilitated by banking authorities on some occasions and laws in some states. 
A reopening could involve an array of incidental transactions, such as changes in the name, charter, capital stock, and legal status of a bank. As with consolidations, the entire package of transaction was recorded as a single event. Rules indicated how to handle confusing cases. For example,

A reopening consequent upon consolidation of two or more suspended banks should be classed as a single reopening. If a suspended national bank reopens as a State bank, however, or vice versa, the transaction must be accounted as a primary organization and not as a reopening (Federal Reserve memo, November 18, 1929).

Thus, if two banks suspended operations, merged a few days later in the morning, and reopened that afternoon, the Federal Reserve recorded two suspensions, one reopening, one liquidation, and no consolidations. The bank whose charter continued in use was listed as reopened. The bank whose charter lapsed was listed as liquidated. If two banks suspended operations, reopened a few days later in the morning, and merged that afternoon, however, the Federal Reserve recorded two suspensions, two reopenings, and one consolidation. If a national bank suspended operations, changed to a state charter, and then reopened for business with exactly the same staff, depositors, and borrowers, the Federal Reserve recorded one national bank suspension, one national bank liquidation, and the opening (i.e. primary organization) of a newly state-chartered bank. If a similar national bank suspended operations, reopened for business, and then adopted a state charter, however, the Federal Reserve recorded one suspension, one reopening, and one conversion from national to state charter.

Completing forms St. 6386c and St. 6386a involved implementing algorithms to determine how to classify complex transactions. Completing the $6386 \mathrm{~b}$ form required additional knowledge, judgment, and effort. The $6386 \mathrm{~b}$ form attributed bank suspensions to one or more of 
five common causes (definitions from Federal Reserve memo, November 5,1930$).{ }^{5}$ The first was slow, doubtful, or worthless paper. The term worthless paper indicated an asset with little or no value. The term doubtful paper meant an asset unlikely to yield book value. Examples included loans to businesses in financial difficulties and securities such as stocks and bonds which had depreciated since purchase. The term slow paper meant an asset likely to yield full value in time, but whose repayment lagged or that could not be converted to full cash value at short notice. An example was a loan to a profitable corporation with cash-flow problems struggled to make timely payments. The term structure prevented the bank from calling in the unpaid balance. Uncertainty over the value of the stream of payments prevented the bank from selling the loan at face value.

The second common cause of suspension was failure a banking correspondent. Correspondents were banks with ongoing relationships facilitated by deposits of funds. Services rendered by correspondents included extending lines of credit, clearing checks, absorbing exchange charges, redeeming coupons from bonds, conducting wire transfers, supplying coins and cash, and facilitating investments in stocks and bonds. A typical situation involved a small state bank outside a reserve city (called a country bank) that deposited funds in a large national bank in a reserve city (called a city bank) and received services in return. Such deposits often formed a large portion of country banks' legal reserves. In many cases, the suspension of the city bank precipitated the suspension of the country bank, because the latter lost its reserves and linkages to the wider financial system.

The third and fourth common causes of suspension were the failure of a large debtor and

\footnotetext{
5 Note that a sixth option existed. Agents completing St. $6386 \mathrm{~b}$ forms could check a box entitled "other cause" and add a description of the phenomenon. The form also contained space for written remarks. About one-third of all forms contained such additional and/or extended comments.
} 
defalcation. Of particular interest were debtors with connections to the bank via overlapping ownership, interlocking directorates, or intermingled management. Defalcation was a monetary deficiency in the accounts of a bank due to fraud or breach of trust for which the management was legally liable. Embezzlement was a common example.

The fifth common cause of suspension was heavy withdrawals. Some banks experienced such large withdrawals that they could no longer continue operations. These deposit declines could be dramatic events in which multitudes of small-account holders lined up in the streets outside of banks hoping to empty their accounts. But, long queues of despondent depositors could be a symptom, rather than a cause, of a bank's demise. Significant deposit losses usually occurred before ordinary men and women lined up on the streets outside of their banks. Businesses, banks, and wealthy individuals possessed the ability to transfer funds quickly via wire or check to other financial institutions. They often also possessed better-than-average information about financial events and transferred large sums out of banks in weeks before ordinary individuals panicked over the safety of their savings or banks suspended payments on deposits. Researchers at the Federal Reserve called these events invisible runs.

The Board of Governors spent several years refining this checklist and teaching representatives how to complete the form. Instructions were straightforward. If acts for which management faced criminal liability precipitated the suspension of payments, check the box labeled defalcation. If the failure of a correspondent or debtor precipitated the suspension of payments, check the appropriate box and note the name of the institution or individual. If withdrawals reduced the liquidity of a bank to the point that it could not continue operations or forced the bank to sell assets at fire sale prices, and thus to choose between suspending payments or suffering insolvency, check the box for heavy withdrawals. If bad assets accumulated to such 
an extent that a bank could not continue operations, either because it could not maintain the necessary cash flow, because it could no longer absorb the losses, or because auditors determined it to be insolvent, check the box for slow, doubtful, and worthless paper. Place the check in the column labeled primary cause if that factor alone forced the bank to suspend operations. Place the check in the column labeled contributing cause if that factor aggravated or accelerated the bank's demise.

Agents often checked multiple boxes, indicating that multiple causes contributed to a bank's suspension. The most common combination was heavy withdrawals and slow, doubtful, and worthless paper. That should be no surprise. Withdrawals forced a bank to suspend payments only if the bank could not convert assets to cash quickly enough to cover claims against it. Bad assets would not force a bank out of business if it retained sufficient deposits and eventually covered its losses. Runs and frozen assets, in other words, could be flip sides of the same coin.

Differences did exist, however, between the asset and liability side of the balance sheet. Agents attempted to communicate these distinctions by marking primary and contributing causes in particular patterns. If the problems precipitating suspension arose on the asset side of a bank's balance sheet, agents checked slow, doubtful, or worthless paper as the primary cause and withdrawals as a contributing cause or not at all. Checking paper as the primary cause indicated that problems with the bank's assets necessitated suspension regardless of other factors. The banks' assets possessed little value. Collections had fallen far behind scheduled. The capital was impaired. The bank was or would soon be insolvent. Checking withdrawals as a contributing cause indicated that depositors' demands exacerbated the situation. Withdrawals could complicate asset problems in several ways. A run on a bank on the edge of insolvency might 
hasten its demise. Fears of runs might force a bank to hold large reserves of liquid assets, such as cash, rather than large portfolios of remunerative assets, such as loans, preventing the bank from earning profits and writing off bad debts. In an effort to satisfy depositors' demands, a bank might sell so many of its good assets that only bad assets remained, or a bank might borrow against so many of its better investments, that it could not earn enough profits to retire its substandard loans.

If the problems precipitating suspension arose on the liability side of the bank's balance sheet, agents checked heavy withdrawals as the primary cause and paper as a contributing cause or not at all. Checking withdrawals as the primary cause indicated that deposits declined to such an extent that the bank could not continue operations. Its reserves of cash were depleted. It could not longer convert assets to currency. It could not satisfy depositors' demands. Checking paper as the contributing cause indicated that the condition of the bank's assets exacerbated the situation. Doubtful and worthless assets could neither be sold nor rediscounted. Slow assets could not be converted to cash quickly enough to alleviate a run. Substandard assets of any kind reduced banks' liquidity and prevented them from converting resources to cash.

If problems arose equally on both sides of the balance sheet, agents checked both withdrawals and paper as primary causes. In this case, the bank's position was doubly difficult. Its assets appeared so problematic that insolvency approached, and its depositors withdrew so much of their savings that illiquidity loomed. Checking two primary causes indicated that either factor alone would have caused the closure of the bank.

Table 1 summarizes the issues discussed in this section. Column (1) indicates the changes in status tracked by the Division of Bank Operations. Column (2) indicates whether a change in status was a form of bank distress. Column (3) indicates which of the changes in status involved 
the creation or dissolution of a bank (or several banks) charters. Column (4) indicates type of St. 6386 form (a, b, or c) on which the information should have been reported. Column (5) contains a concise definition of the change in status. For exact definitions and a clarification of borderline cases, please consult the discussion above.

\section{Section 3: Data Sources and Cross-Validation}

This section delves into details of the data collection process and the procedures that the Federal Reserve used to validate and cross-check the evidence. The purpose of the extended discussion is to reassure the reader of the veracity of the Federal Reserve's observations, illuminate their value for historical research, and elucidate the information available in the database, so that readers may effectively employ it in their own research.

The Board of Governors strove to gather information about causes of suspension from the man on the spot who knew the facts of the issue at hand. Annotations on the forms reveal these efforts. Comments on hundreds of forms indicate that the information agrees with the receiver's report or was taken "From receiver's report as of date of closing," a phrase often imprinted with an ink stamp. Federal Reserve agents often communicated directly with receivers, requesting additional information or inquiring about complex or unclear cases. Receivers' replies appear on many forms. For example, the receiver for Mayo's Money Exchange Bank of San Antonio, Texas, stated "the primary cause of failure was due to investments of funds in stocks and bonds representing real estate investments." The Central Bank and Trust Company of Chicago, Illinois, which was the liquidation trustee of the Mecca Bank of Mecca, Indiana, stated the bank should be classified as a voluntary liquidation because "all of the creditors will be paid off in full within a reasonable period.” A letter dated 6 October 1932 and written by F. E. J. Bower, the receiver

for the First National Bank of Bradley Beach, New Jersey, described the "reorganization plan as 
follows: Creditors were to waive $40 \%$ of claims against the closed bank, total amounts of such waiver equal $90 \%$ of present liabilities. Old stock of bank ( $\$ 100$ par) to be surrendered and then resold at \$25 per share in this way raising $\$ 125,000$.”

The Division of Bank Operations also consulted call reports and examination reports and communicated directly with bank examiners and banking departments. Examples abound. The examiner of the Central National Bank in Bartleaville, Oklahoma, which suspended on March 22,1930 , classified “ $\$ 235,000$ of assets as worthless and $\$ 164,000$ as doubtful." The examiner of the First National Bank of Bixby, Oklahoma, which suspended on February 18, 1929, stated "the suspension of this bank is chargeable directly to top heavy and other ill-advised loans made during the period of inflation following the recent war, together with the incompetency of succeeding officers in the matter of enforcing any effective policy of collection over the following period of deflation." On 28 February 1931, a letter from the Bank Commissioner of Connecticut stated

the Central Fairfield Trust Company of Norwalk, now the Merchants Bank and Trust Company, resumed business on Friday, February 20, 1931. The name of the institution was changed by special act of the legislature. While the name has been changed, it is still the same corporation which has resumed business upon the discharge of the temporary receiver appointed by the courts.

In January 1930, a telegram from the Indiana State Banking Department explained the complicated series of transactions surrounding the suspension of the Argos State Bank of Argos, Indiana, and its reopening under a new charter. In March 1933, the Utah State Bank Commissioner reported that Gunnison Valley Bank of Gunnison, Utah, would reopen shortly. On 27 March 1930, an employee of the Division of Bank Operations with the initials M.F. called Mr. Gough of the Comptroller of Currency after "examination of agent's reports proved inadequate." Mr. Gough explained that the myriad of transactions reported for the town of 
Bartow, Florida, pertained to the closure of a single institution, the Polk County National Bank, which unsuccessfully attempted to shed dubious assets, change its charter, and establish itself as a new bank under a different name in hopes of saving itself.

The Division of Bank Operations also contacted institutions and individuals with local knowledge of particular banks. Local courts provided access to liquidation records, names and addresses of court-appointed receivers, and opinions about suspended banks under their jurisdiction. Local postmasters provided another means to attain such information. For example, on 10 December 1930, a letter from the postmaster at Sandia, Texas, informed the Federal Reserve that W.T. Mumme, the private bank in the town, ceased operations and liquidated voluntarily.

For country banks, a good source of information was their banking correspondent. Correspondents in reserve cities held deposits of county-bank clients, provided clients with services such as check clearing and wire transfers, and monitored clients' financial health and creditworthiness. Correspondents frequently replied to inquiries concerning the closures of the clients. Many examples exist. The correspondent of Juan McKeyes and Company, a private bank in Lawton, Michigan, wrote that McKeyes suspended operations on May 9, 1932 due to the financial consequences of grape crop failures in the area, and reopened on June $2^{\text {nd }}$ of that year

after its depositors of their own volition had signed waiver agreements providing that no funds except such as are deposited after the bank reopened would be withdraw for a period of five years. Under the circumstances the court having jurisdiction over its affairs dismissed the receivership petition.

The Continental Illinois Bank and Trust Company, which was the correspondent of the Commercial Bank of Wapellow, Iowa, stated that the latter closed its doors on October 13, 1931, because the ...

bank unwisely expanded loans to care for needs of borrowers in communities 
where banks had suspended and found itself unable to meet shrinkage in its deposits due to unrest among its own customers.

The Valley National Bank of Des Moines, Iowa stated that its client, the Farmers and Merchants Bank of Scranton, Iowa, suspended operations primarily because it was "loaded with slow, doubtful, and worthless paper."

Banks provided information about their own conditions. Reopened banks answered inquiries about the cause of their temporary suspensions and the conditions under which they reopened. Banks entering into voluntary liquidation released public statements explaining how and why. Even the management of failed banks provided information in instances when Federal Reserve agents contacted them directly. For example, in the fall of 1930, Harry M. Wilcox, the President of the Citizens Bank of North Adams, Michigan, replied to an inquiry about the cause of his bank's suspension by stating "general business depression and decline in land value caused the bank to close its doors." Federal Reserve agents could gather this information because they possessed the legal authority to compel truthful testimony. The law required bankers to answer their inquiries. Untruthful respondents could be prosecuted for perjury. Federal Reserve agents seeking answers from reticent witnesses could ask the Office of the Comptroller of Currency (OCC) for assistance. OCC examiners could compel a response, since they possessed investigative powers identical to secret service agents.

Federal Reserve agents consulted the publications of the state banking departments. ${ }^{6}$ Most banking departments published annual reports. A few published biennially. Many banking departments also published summaries of bank changes in the interim. Periodicity varied across states. Indiana published a monthly bulletin. The New York State Banking Department published 
a weekly bulletin with detailed descriptions of the causes of each state bank suspension. The

New York Superintendent of Banks also released an announcement at the time of each bank suspension, stating the reasons why it was "deemed unsafe and inexpedient to permit the institution to continue in business." The Federal Reserve banks also compiled monthly summaries of bank changes, which they forwarded to the Board's Division of Bank Operations.

Federal Reserve agents also consulted an array of business periodicals and popular dailies. Citations to the following appear on the 6386 forms:

- Commercial and Financial Chronicle

- Bankers' Monthly

- New York Sun

- New York Times

- Polk's Bankers Encyclopedia

- Rand McNally Bankers Directory

- Reports of R.G. Dunn \& Company

Numerous newspapers from locales around the United States were also cited, but the typists who transcribed the newspaper clippings merely stated that their source was a 'local newspaper' without additional bibliographic details.

Each of these sources possessed its own strength. Federal Reserve officers had direct and continuous contact with the management of member banks and the ability to comment credibly on their competency. Correspondents could also provide vivid and valuable testimony on this issue. Correspondents had ongoing relationships with the management of client banks, and tracked the quality of their clients' portfolios in case decisions had to be made about the extension of credit. Call, examiners', and receivers' reports yielded financial data including the kind, quality, and quantity of assets possessed by a bank on the date of suspension and the

6 Katherine Tunis, head of the research library of the Board of Governors, reports that the Board's library retained copies of all publications from the state banking departments until the late 1970s, when to conserve shelf space, the library sent all of these publications to the libraries of the Federal Reserve district banks. 
patterns of deposit inflows and outflows before that date. Examiners of all national and most state banks classified assets according to the categories good, slow, doubtful, and worthless, which the Federal Reserve used on its suspension forms. Receivers of national and state banks also listed assets and estimated values. Discussions with examiners, receivers, correspondents, and bankers provided expert opinions about phenomena that they observed, often over a period of years. Particularly useful are their opinions about the quality of the management and the importance of correspondent linkages. Newspapers provided detailed descriptions of events that interested their readers, such as defalcations and bank runs, and on important financial events in their hometowns, such as the closing and reopening of local banks. Much of the information provided by these sources could come from nowhere else.

The Federal Reserve Board incorporated all of this information into the 6386 forms by creating a nationwide reporting network. The law required member banks to report changes in status to their local Federal Reserve Bank. Similar regulations required national banks to report such information to the Office of the Comptroller of the Currency. Federal Reserve agents at district and branch banks completed initial drafts of the forms from information at their disposal and forwarded the forms to the Board of Governors in Washington, where the Division of Bank Operations checked the information against available sources (including copies of the materials submitted to the OCC and routinely forwarded to the Federal Reserve), sorted and tabulated the forms, compiled aggregate statistics, and disseminated the results. Nonmember banks reported to state authorities, which cooperated in the Federal Reserve's data-collection endeavors by forwarding the relevant information. The Federal Reserve cultivated contacts with state agencies, and during the Depression, subsidized the salaries of state employees who worked part time on Board businesses. 
In complicated, unclear, and unresolved cases, the Division requested additional information and researched the events in greater depth. The definitive determination of the cause of a bank suspension often took several months. The archives contain preliminary, in-process, and final reports for many banks. These duplicates accumulated as agents incorporated additional information into their analysis and updated their conclusions. Information flowed to the Division of Bank Operations as institutions and individuals replied to Federal Reserve requests for information. In several cases, the materials collected by the Division, such as examiners' reports, telegrams from receivers, press clippings, etcetera, remain clipped to the 6386 forms, although routine procedure appears to have been to discard the source material after reaching a definitive determination of the cause of a bank's failure

The Board's efforts continued throughout the Depression. After the national banking holiday, the Board joined forces with the Office of the Comptroller of Currency and the Federal Deposit Insurance Corporation. With funding from the Works Project Administration, this regulatory triumvirate strove to construct a data base containing information from all banks operating in the United States since 1929. As part of the process, the Board of Governors rechecked the 6386 forms against the records of the state banking bureaus, the OCC, and the Rand McNally and Polk corporations. The Board published the initial results of this reconciliation in the Federal Reserve Bulletin for September, 1937. Further publications were planned, but the project lapsed as the Board allocated resources towards other projects.

\section{Section 4: The Accuracy of the Archival Information}

The previous sections describe how the Board of Governors gathered information about events effecting banks and how the Division of Bank Operations determined the cause of each bank's demise. The method involved gathering financial data for each institution; talking with 
the regulators, examiners, receivers, correspondents, and bankers who knew the facts of the issue at hand; applying a set of algorithms devised to determine the cause of the failure; and reporting the results in a lexicon devised to convey the conclusions clearly, concisely, and consistently.

This section compares the archival evidence to tabulations previously published in FRB'37, a wide array of historical sources, and numerous scholarly studies. The comparisons demonstrate four important points. One, the archives retain the original data set in its entirety. Two, the archival information on events effecting banks is accurate. The information matches facts revealed by other sources. Three, the archival information on the causes of bank suspensions is accurate. The information matches conclusions drawn from historical studies of particular institutions and econometric studies of the broader financial system. Four, the archival evidence contains information previously unavailable to scholars.

The initial question one should ask about the archival evidence is: do figures from it correspond closely to the figures published in the FRB'37? Figures 1 and 2 answer that question. In Figure 1, the solid line is the number of bank suspensions each month according to FRB'37. This tally includes all banks: national, state, and private. The dotted line represents the archival data. It is calculated from the St. 6386 forms in the National Archives using the definitions, rules, and algorithms established by the Division of Bank Operations in the 1930s. The lines correspond closely. The coefficient of correlation for the two series is 0.996 .

In Figure 2, the solid line is total deposits in the banks that suspended each month according to FRB'37. This tally includes all banks and both temporary and terminal suspensions. The dotted line represents the archival data. It is calculated from the St. 6386 forms in the National Archives using the definitions, rules, and algorithms established by the Division of Bank Operations in the 1930s. The lines correspond closely. The correlation coefficient for the 
two series is 0.998 .

Similar exercises on other cross-tabulations duplicate the analogous series published in 1937. The replication of the FRB'37 series demonstrates that the archival data remains comprehensive. The dataset retains observations for all (or almost all) of the banks represented by the FRB'37 series. A discrepancy between the two series exists during the first five months of 1929. In each month, the archival data contains 15 to 30 fewer suspensions than the published tabulations. I have not been able to determine the source of this discrepancy. I suspect the cause lies in the Federal Reserves transition to a new reporting system beginning in January 1929. After July 1929 (i.e. after the start of the contraction), the archival and published series are nearly congruent. From July 1929 to February 1933, the correlation coefficient between the archival and published series is 0.999 .

The slight discrepancies after July 1929 appear to be due to duplicate entries in the data set and complicated or unclear cases where properly applying the coding algorithms is difficult. The most common complications was a bank that suspended operations and then consolidated with another institution. If the suspended bank reopened for business (for even a brief moment) prior to consolidation, then the Division of Bank Operation's algorithms reported these events as a bank suspension (temporary), a reopening, and a consolidation (i.e. three transactions on three separate dates). If the banks did not officially reopen, then the algorithm classified this transaction as a terminal suspension (on the original date of suspension). In approximately 25 cases, information in the St 6386 forms did not clearly indicate the order of events and the appropriate classification of the transaction. In several cases, preliminary St 6386 forms contradicted revised St 6386 about the relevant details. Reference to contemporary publications such as newspapers and state banking reports - did not clarify the situation. So, in all of these 
cases, I have assumed that the bank did reopen prior to consolidation, and that the events should be recorded as a temporary suspension, a reopening, and a consolidation.

Additional reassurance of the accuracy of the archival information comes from state-level databases which I have constructed by combining information from government (state examiners, Fed, and OCC reports) and commercial sources (Rand McNally's Bankers Directory and Polk's Bankers Encyclopedia). For the four states that I have completed, Florida, Mississippi, New York, and Tennessee, information about changes in bank status in the statelevel databases and St. 6386 forms match at rates over $99.5 \%$. The few discrepancies appear to be temporary suspensions (which were not recorded in many sources) and incorrect St. 6386 forms (for example, misspellings of bank names and locations and incorrect transaction dates). The striking similarities between datasets derived from these independent sources suggests that the archival dataset contains observations for all banks that suspended operations during the Great Contraction.

Does the quality of archival information about the causes of bank suspensions equal the quality of information on the timing and nature of changes in bank status? A thorough investigation of the evidence indicates that the answer is yes. This conclusion rests on three facts.

First, for individual institutions whose demise has been the subject of academic analysis, the conclusion of scholars coincides closely with the cause of suspension indicated on the relevant St. 6386b form. For example, Wicker (1980) and McFerrin (1939) attribute the demise of the Bank of Tennessee (Nashville, TN), the principal bank of the Caldwell conglomerate, to an ill-informed strategy that lead to large investment losses. Wicker (1980) and McFerrin (1939) attribute the demise of the American Exchange Trust Company (Little Rock, AR), a Caldwell affiliate, to runs on the institution. The corresponding St. 6386 forms attribute the Bank of 
Tennessee's suspension to "depreciation in value of securities" and excessive debts on real estate and bills payable. The corresponding St. 6386 forms attribute the American Exchange Trust Company's suspension to "heavy withdrawals due to rumors caused by failure of Caldwell and Company, Nashville Tenn."

Friedman and Schwartz (1963) and Joseph Lucia (1985) attribute the failure of The Bank of United States to its large, underperforming real estate portfolio, which threatened its solvency and prevented it from merging with other institutions, and to "runs on several of the bank's branches (Friedman and Schwartz, p. 310, note 9).” The corresponding St. 6386 form attributes the suspension to the primary cause of "slow, doubtful, and worthless paper" with the contributing cause of "heavy withdrawals."

Second, for broader events that have been the subject of academic analysis, the academic conclusions coincide closely with the causes of suspension indicated on the relevant St. 6386b forms. For example, Friedman and Schwartz (1963) attribute the surge in suspensions during March 1931 to the public's "resumed conversion of deposits into currency." The St. 6386 forms paint a similar picture. Federal Reserve agents reported that heavy withdrawals were the primary cause of almost of the suspensions and stated laconically on most of the forms that the bank closed its doors after runs depleted its cash reserves.

Calomiris and Mason (1997) attribute the Chicago banking panic of June 1932 to depositors' confusion about bank asset quality. Depositors withdrew funds widely from banks which they feared might be insolvent, because they did not know which institutions were, in fact, insolvent. The St. 6386 forms tell a similar tale. For the preponderance of the banks which failed during the panic, examiners concluded that the primary cause of suspension was doubtful and worthless assets. Runs on these institutions were a contributing cause of their closure. Written 
comments on the suspension forms indicate that banks suffered from declines in the value of securities, bonds, and real estate and from large loan losses.

Three, conclusions drawn from econometric studies of the causes of bank suspensions correspond closely with the causes of suspension indicated on the relevant St. 6386b forms. One example is the study by Calomiris and Mason (1997) discussed above. Another example comes from my study of bank suspensions in the state of Mississippi. In 1929, the industrial depression and the failure of local businesses caused the closure of banks in the surrounding community. These closures were concentrated in the southern half of the state under the jurisdiction of the $6^{\text {th }}$ Federal Reserve District. In 1930, a banking panic swept through the state, forcing large numbers of banks to suspend operations in the $6^{\text {th }}$ District and an even higher percentage to suspend operations in the northern half of the state, which was under the jurisdiction of the $8^{\text {th }}$ Federal Reserve District.

Table 2 presents predictions from a parsimonious probit model using bank and county characteristics in July 1929 to predict suspensions between July 1929 and June 1930. The table also uses the coefficients from the 1929 regression and characteristics of banks and counties in July 1930 to predict suspension rates between July 1930 and June 1931. Column (i) indicates the average predicted probability of suspension for 1929. Column (iii) indicates the actual suspension rate in 1929. The null hypothesis that the former equals the latter cannot be rejected, demonstrating that the model fits the data reasonably well. Column (ii) indicates the average predicted probability of suspension for 1930 . The prediction for the $8^{\text {th }}$ District changes little, because the balance sheets of banks in the $8^{\text {th }}$ District changed little between July 1929 and July 1930. The prediction for the $6^{\text {th }}$ District falls substantially, because the $6^{\text {th }}$ Districts high failure rate for 1929 was driven by adverse shocks in particular counties. In 1930, fewer banks operate 
in those counties (in fact, almost all of the banks in those counties failed). In the remainder of the district, the balance sheets of banks, and thus the predicted probability of failure, changed little. Comparing Columns (ii) and (iv) shows that our model of fundamentals which fit the data well for 1929 does not predict the events that occurred in the following year.

The standard interpretation of these regression results is that fundamentals caused banks to fail in 1929 while unpredictable panics caused the failures one year later. The archival evidence concurs with this conclusion. The St. 6386 forms indicate that the most common cause of suspension in 1929 was problematic assets. Written comments reveal idiosyncratic shocks such as a "large saw mill closing down caused withdrawal of deposits." The St. 6386 forms indicate that the most common cause of suspension in 1930 was heavy withdrawals. Half of the suspensions were temporary. In sum, in the Mississippi case, the causes of suspension indicated on the St. 6386 forms are consistent with the econometric evidence.

The veracity of the archival evidence raises the question: what information is available in the new dataset? What does the data reveal? Figure 3 summarizes the available information. The solid black area at the bottom indicates the new observations on bank distress. The new observations consist of voluntary liquidations and consolidations due to financial difficulties. The gray area indicates the number of temporary bank suspensions. The FRB' 37 reported these suspensions, but did not differentiate them from permanent suspensions. The vertically striped area indicates the number of terminal suspensions. The entire shaded area indicates the total number of bank changes due to financial difficulties that occurred each week from January 1929 through March 1933. For all of these observations, the archival database adds an array of information including the cause of the suspension, the date of the suspension, the financial condition of the bank on that date, the identity of the institution or individuals who initiated the 
change, and in many cases, written comments concerning the circumstances leading to and/or resulting from the event.

Three patterns in the new data should be noted. First, the new observations are clustered between the fall of 1930 and winter of 1932. During that period, bank suspensions surged above

pre-depression levels in repeated waves. Second, the archival evidence allows us to view the data without chronological aggregation. Weekly and daily series of suspensions display volatility much greater than the monthly series published in FRB'37. On several occasions, the number of bank suspensions rose (or fell) overnight by a factor of 20 or more. Such wild swings may be one reason that bank failures made such an impression on public perceptions.

Third, the banking holiday of March 1933 does not appear in the archival evidence. Why not? The Federal Reserve's reporting system was not designed to (and for that reason did not) track the status of banks that closed during state or national banking holidays. The Division of Bank Operations provided an approximation (4000) of the number of banks that did not reopen within three months of the national banking holiday, which was published (with caveats) in FRB'37. The exact number is unknown. This lacuna in the evidence is a problem universal to all data sets. No extant source describes this event in detail.

\section{Section 5: Chronological Data on Categories of Distress and Causes of Suspensions}

The previous sections described the nature and properties of the archival evidence. This section presents aggregate series constructed from this rediscovered source. The series are designed to illuminate the nature of the banking crises during the early 1930s, to supplement (and in some cases replace) the series in FRB'37, and to enable economic historians and macroeconomists to accurately assess the causes and consequences of the contraction.

Tables 3 and 4 present annual hazard rates for categories and causes of distress. Table 3 
focuses on permanent bank changes. Table 4 focuses on the causes of temporary suspensions. In the tables, row (a) indicates the total number of banks suspending operations. Row (a.1) indicates the total number of banks suspending operations due to problems with assets and liabilities. Imbalances often arose on one side of the balance sheet, but could arise simultaneously on both sides. Rows (a.1.1) through (a.1.5) display the possible combinations: (a.1.1) slow, doubtful, or worthless assets listed as the primary cause of suspension; (a.1.2) assets listed as the primary cause and heavy withdrawals listed as a contributing cause; (a.1.3) both withdrawals and assets listed as primary causes; (a.1.4) heavy withdrawals listed as the primary cause and assets as the contributing cause; and (a.1.5) withdrawals alone as the primary cause of suspension. Row (a.2) indicates the number of banks suspending due to the closure of a correspondent. Row (a.3) indicates the number of banks suspending due to defalcations, mismanagement, excessive loans to officers and directors, excessive investment in building and facilities, and similar circumstances. Row (a.4) indicates the number of banks suspending due to other or multiple causes. The latter consists in part of complex cases which do not fit into the mutually exclusive categories above, often because they spanned two or more classifications. An example is a poorly managed bank which failed to enforce collections on its slow farm loans and which experienced runs after local newspapers revealed that its president embezzled funds from savings accounts. Row (b) indicates the number of consolidations due to financial difficulties. Row (c) indicates the number of voluntary liquidations. Row (d) indicates the number of net changes for reasons unrelated to financial difficulties. This series consists almost entirely of the number of mergers minus the number of new openings.

Table 5 indicates the number of banks in distress by category and quarter. The quarters are defined as winter (January, February, and March), spring (April, May, and June), summer 
(July, August, September), and fall (October, November, and December). Columns (1) through (3) refer to the three categories of distress - terminal suspensions, voluntary liquidations, and consolidations due to financial difficulties - in which banks departed from the banking business. Column (4) indicates the total of the first three columns. Column (5) indicates the number of temporary bank suspensions - a form of distress in which banks remained in business. Column (6) indicates the total number of banks in distress (i.e. Columns (1) $+(2)+(3)+(5))$.

The figures in Table 5 can be compared to Tables 1 and 12 of FRB'37. Those tables report total number of bank suspensions, which is equivalent to the sum of Columns (1) and (5) in Table 5 of this essay. Scholars studying the macroeconomic effects of bank suspensions should rely on the FRB'37 series for the years 1927 through 1928 and 1933 through 1936, for which there is little evidence of temporary bank suspensions. Scholars should interpret results for the period 1921 through 1926 with caution, because narrative reports of temporary suspensions exist, but data distinguishing temporary from permanent suspensions does not. Scholars should employ bank suspension data from this essay when studying the contraction of the early 1930s (i.e. summer 1929 through winter 1933), because the series of temporary suspensions peaks in the Fall of 1930 and the Fall of 1931. Those quarters contain breaks in trend for many macroeconomic time series (including money supply, interest rates, and output), and those quarters tend to be the outliers that identify relationships in most macroeconomic models.

Table 6 reports deposits in banks in distress by category and quarter in thousands of dollars. Figures from this table can be compared to Tables 2 and 13 of FRB'37, which report total deposits in suspending banks, which is equivalent to the sum of deposits in banks suspending temporarily and terminally (i.e. the sum of Columns (1) and (5)). Scholars studying the macroeconomic effects of deposits in suspending banks should treat this data in the same manner 
as they treat data on the number of suspensions. For the years 1927 through 1928 and 1933 through 1936, rely on FRB'37. For the period 1921 through 1926, interpret results with caution. For the period winter 1929 through winter 1933, employ the new data separating total deposits in suspending banks into terminal and temporary components.

Scholars studying data on deposits should keep in mind an additional caveat. Form St. 6386a, which reported bank consolidations, and Form 6386c, which reported voluntary liquidations, did not contain a space for information on deposits. On occasion, Federal Reserve agents included this information. For that reason, dollar values of deposits appear in the spreadsheet in Columns (2) and (3), but those figures are far from complete, and do not systematically represent dollar values of deposits in banks consolidating due to financial difficulties or undergoing voluntary liquidation.

Table 7 reports loans and investments in banks in distress by category and quarter in thousands of dollars. Figures from this table can be compared to Table 3 of FRB'37, which reports loans and investments in suspending banks, which is equivalent to the sum of loans and investments in banks suspending temporarily and terminally (i.e. the sum of Columns (1) and (5)). Scholars studying the macroeconomic effects of loans and investments should treat this data in the same manner as they treat data from the previous two tables. For the years 1927 through 1928 and 1933 through 1936, rely on FRB'37. For the period 1921 through 1926, interpret results with caution. For the period 1929 through winter 1933, employ use this table to separate loans and investments in suspending banks into their total and temporary components.

The data on loans and investments in Table 7 has an advantage over the data on deposits in Table 6. All three St. 6386 forms report this information for banks on the date of a change in status (i.e. suspension, liquidation, or consolidation). This information reveals, therefore, the 
relative significance of different categories of distress, as measured by the productive assets of the banks involved. The bottom line of Table 7 illuminates this issue. During the contraction, loans and investments of the 5,191 banks suspending permanently amounted to $\$ 3.6$ billion. Loans and investments of the 877 banks suspending temporarily amounted to $\$ 607$ million. Loans and investments of the 659 banks consolidating due to financial difficulties amounted to $\$ 1.7$ billion. Most of these consolidations occurred during panics in the period beginning in the fall of 1930 and continuing until the winter of 1932. The peak occurred during the fall of 1931, after Britain abandoned the gold standard and the Federal Reserve raised the discount rate to stem financial outflows. During that quarter, banks with assets totaling \$725 million consolidated in the face of financial difficulties. Banks with loans and investments totaling \$698 million suspended operations terminally. Banks with loans and investments totaling \$291 million suspended operations temporarily.

Tables 8 through 10 report the causes of terminal bank suspensions. The columns of the table have the same definitions as the rows of Table 3, and are labeled accordingly. Table 8 indicates the number of terminal suspensions by cause and quarter. Table 9 indicates deposits in banks suspending permanently in millions of dollars. Table 10 indicates loans and investments in banks suspending permanently in millions of dollars.

Tables 11 through 13 report the causes of temporary bank suspensions. The columns of the table have the same definitions as the rows of Table 3. Table 11 indicates the number of temporary suspensions by cause and quarter. Table 12 indicates deposits in banks suspending temporarily in millions of dollars. Table 13 indicates loans and investments in banks suspending temporarily in millions of dollars.

Tables 8 through 13 have no counterpart in FRB'37. The Federal Reserve never 
published data on the causes of suspensions during the Great Contraction. Scholars interested in the macroeconomic implications of these series must restrict their attention to the early 1930s. Reasonable assumptions, however, should allow them to extend the series forward. The number of banks suspending operations dropped dramatically after March 1933. In 1934, only 57 banks suspended operations. In 1935 and 1936, the number of suspensions was 34 and 44 respectively. In 1934, Congress established the Federal Deposit Insurance Corporation. In the years that followed, depositors returned funds to financial institutions, and banks held tremendous quantities of cash reserves. In this environment, it seems probable that unlucky investments, idiosyncratic asset shocks, and mistakes of management caused the bulk of bank failures, and that bank runs and contagion through correspondent networks played a lesser part. So, macroeconomists may be able to safely assume that the bulk of bank suspensions during the late 1930s stemmed from fundamental forces rather than the panics that appear to have plagued the banking system at some points in the past.

\section{Section 6: Discussion}

The evidence introduced in this essay has the potential to resolve many debates concerning the causes and consequences of the banking crises during the Great Depression. Academic debate continues because scholars lack detailed, comprehensive data on the nature and timing of events. The St. 6386 database provides such evidence.

Quarterly series of data constructed from the St. 6386 database make this information available to scholars studying the macroeconomic aspects of the contraction. These series supplement those published in the Federal Reserve Bulletin of 1937, enabling scholars to make important distinctions between different forms of bank distress. For example, scholars can now

distinguish temporary from terminal suspensions. These two types of suspensions have different 
macroeconomic implications. Temporary suspensions indicate periods of illiquidity when solvent banks temporarily suspend the conversion of deposits to currency and when depositors demands for currency increase to quickly for the financial system to respond. Temporary suspensions reflect periods where the monetary problems described by Friedman and Schwartz (1963) afflict the economy. Terminal suspensions indicate periods when banks cease operations, depositors lose access to their savings, and borrowers lose access to sources of credit. Terminal suspensions reflect periods of disintermediation where the non-monetary dynamics outlined by Bernanke (1983) afflict the economy.

The new series also enables scholars to observe events that could not be observed in the past. For example, now scholars can observe consolidations due to financial difficulties (usually consummated quickly in a rush to avoid suspension). The concentration of these consolidations during the fall of 1931 may alter interpretations of that event. Could it be possible, for example, that by forcing banks to consolidate, the banking crisis following Britain's departure from the gold standard reduced the competition among financial institutions, raising interest rates on commercial loans, even though the banks remained open for business?

The data series introduced in this essay should enable scholars to answer this and many other questions concerning the financial crises of the early 1930s. 
Figure 1

Comparing Archival and Published Data

Number of Bank Suspensions, by Month, January 1929 to March 1933

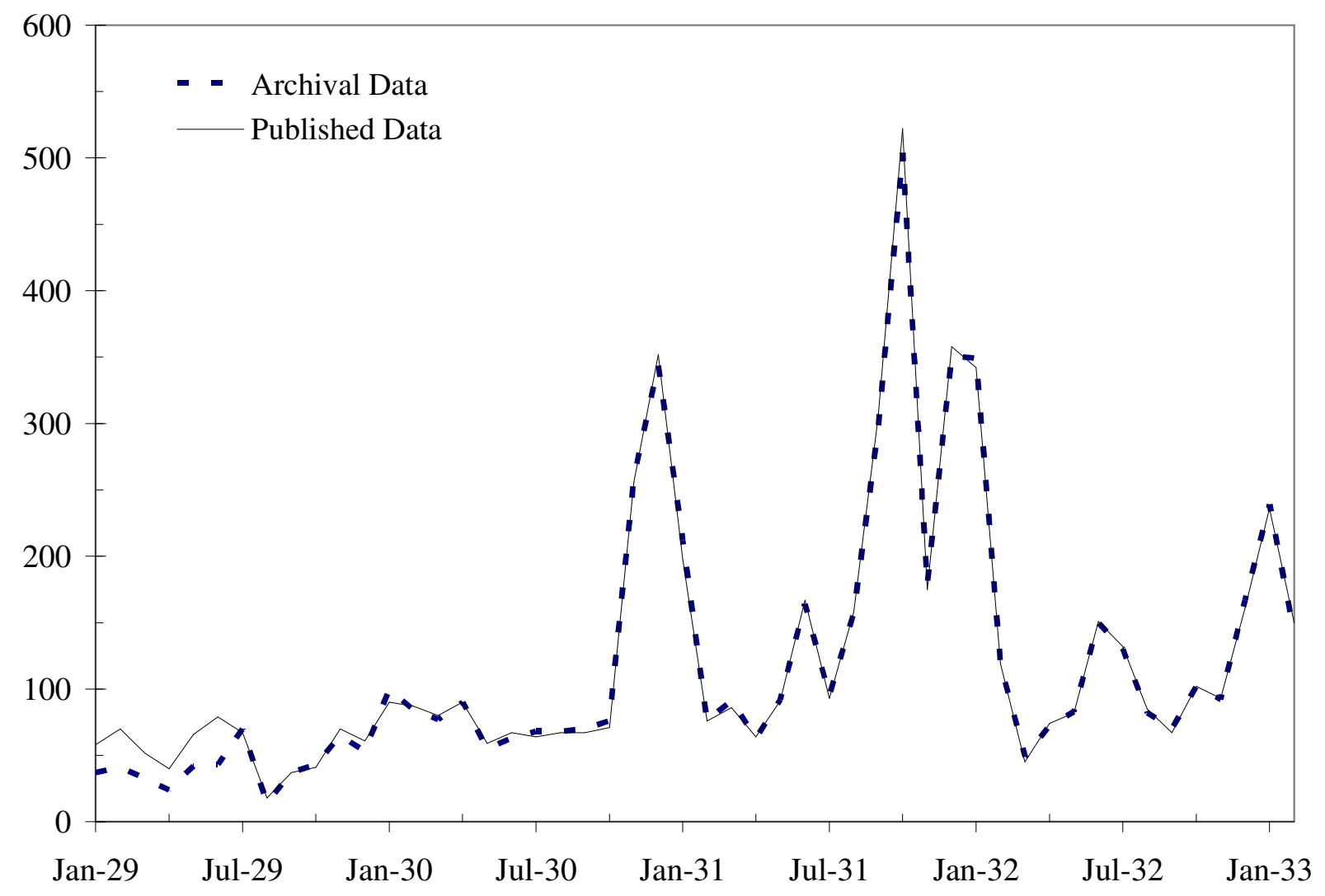

Sources: Archival data from National Archives and Record Administration, Record Group 82, as described in appendix. Published data from Federal Reserve Bulletin, September 1937, Table 12, p. 907 
Figure 2

Comparing Archival and Published Data

Deposits in Suspended Banks, Millions of Dollars, by Month, January 1929 to March 1933

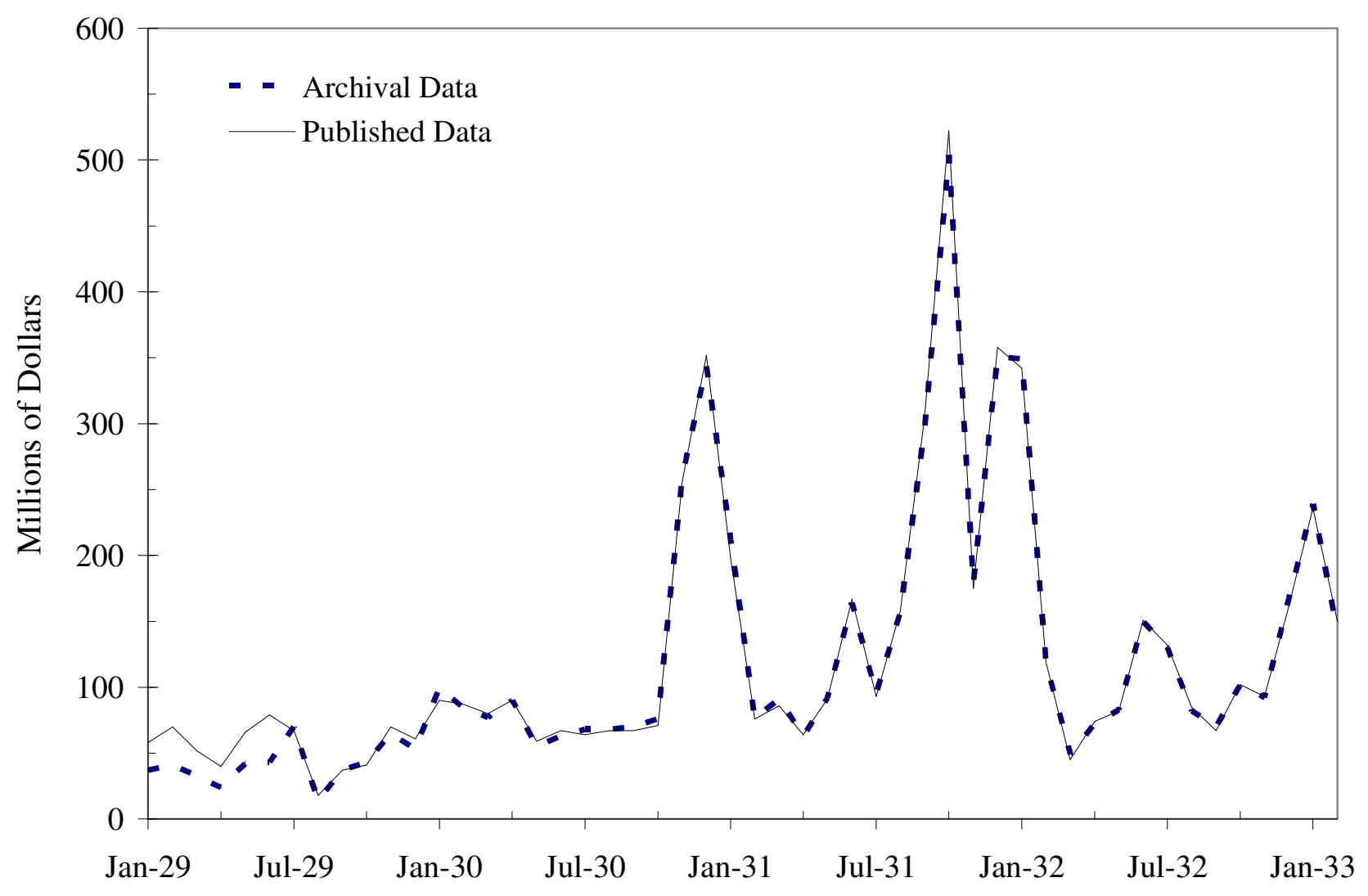

Sources: Archival data from National Archives and Record Administration, Record Group 82, as described in appendix. Published data from Federal Reserve Bulletin, September 1937, Table 13, p. 909 
Figure 3

Comparing Archival and Extant Data

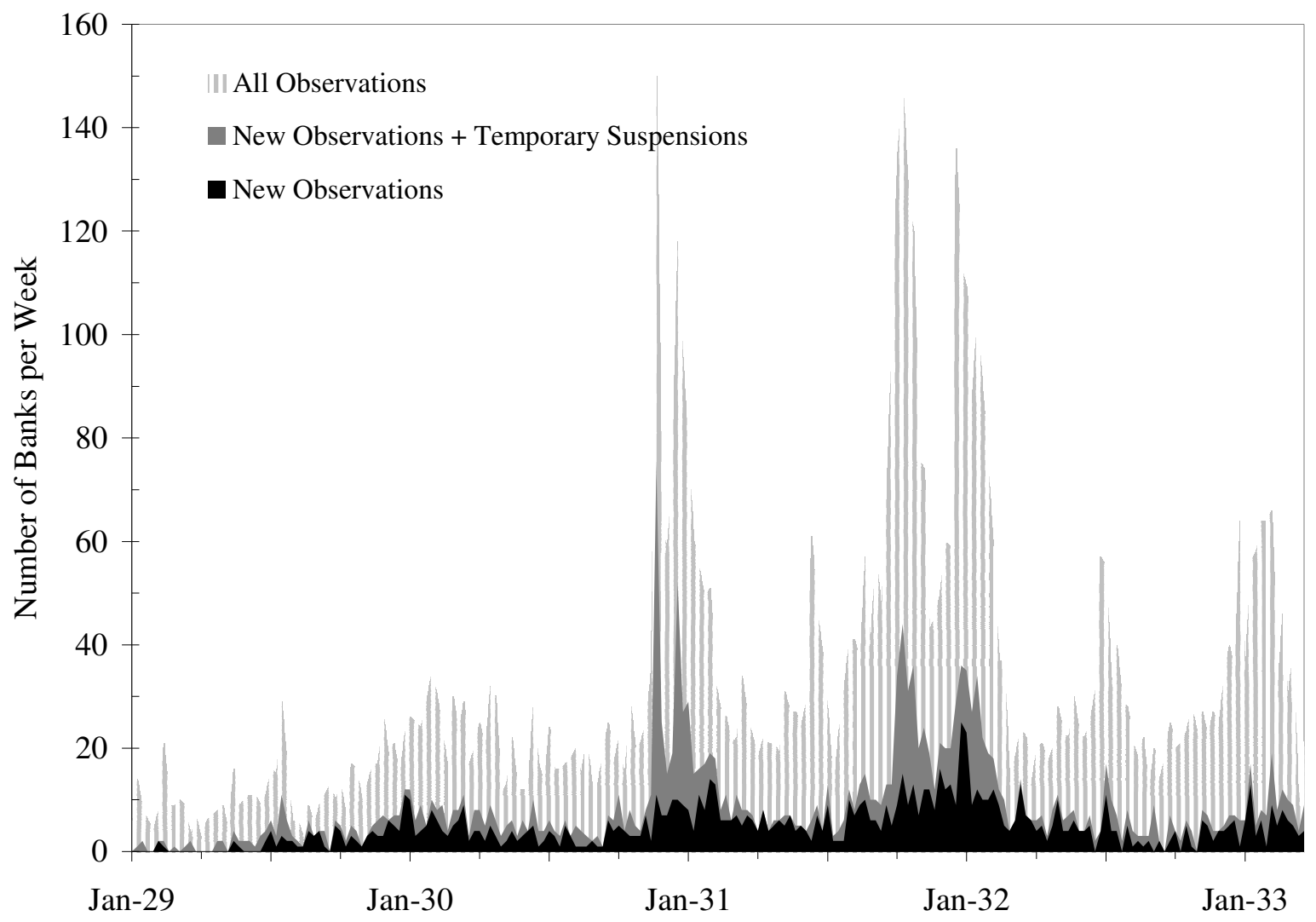

Notes: Solid black area indicates the number of voluntary liquidations plus consolidations in financial difficulties. The gray area indicates the number of temporary suspensions. The vertically striped area indicates the number of terminal suspension. The sum of these three categories is the total number of new and extant observations (i.e. all observations).

Source: National Archives and Records Administration. 
Table 1

Changes in Bank Status, Definitions and Sources

January 1929 through March 1933

\begin{tabular}{|c|c|c|c|c|}
\hline Change in Status & Distress? & $\begin{array}{l}\text { Change } \\
\text { in Charter? }\end{array}$ & $\begin{array}{l}\text { Source } \\
\text { St. } 6386\end{array}$ & Brief Definition. A bank that ... \\
\hline $\begin{array}{l}\text { Suspension, Terminal } \\
\text { Suspension, Temporary }\end{array}$ & $\begin{array}{l}\text { Yes } \\
\text { Yes }\end{array}$ & Yes & $\begin{array}{l}\mathrm{b} \\
\mathrm{b}, \mathrm{c}\end{array}$ & $\begin{array}{l}\text { Ceased operations and entered liquidation under supervision of a receiver. } \\
\text { Ceased operations temporarily and then reopened for business. }\end{array}$ \\
\hline Voluntary Liquidation & Yes & Yes & $\mathrm{c}$ & Ceased operations and rapidly repaid depositors the full value of deposits. \\
\hline $\begin{array}{l}\text { Consolidation in financial difficulties } \\
\text { Consolidation }\end{array}$ & Yes & $\begin{array}{l}\text { Yes } \\
\text { Yes }\end{array}$ & $\begin{array}{l}\mathrm{a} \\
\mathrm{a}\end{array}$ & $\begin{array}{l}\text { Merged with another bank while at risk of suspension or liquidation. } \\
\text { Merged with another bank while in a sound financial position. }\end{array}$ \\
\hline Organization of New Bank & & Yes & $\mathrm{c}$ & Acquired a charter and opened its doors to depositors. \\
\hline $\begin{array}{l}\text { Conversion - Nonmember to member } \\
\text { Conversion - Member to nonmember } \\
\text { Conversion - State to national charter } \\
\text { Conversion - National to state charter }\end{array}$ & & $\begin{array}{l}\text { Yes } \\
\text { Yes }\end{array}$ & $\begin{array}{l}\mathrm{c} \\
\mathrm{c}\end{array}$ & $\begin{array}{l}\text { Joined the Federal Reserve System. } \\
\text { Departed from the Federal Reserve System. } \\
\text { Surrendered state charter but continued under a new, national charter. } \\
\text { Surrendered national charter but continued under a new, state charter. }\end{array}$ \\
\hline $\begin{array}{l}\text { Change in capital stock } \\
\text { Change in street address }\end{array}$ & & & $\begin{array}{l}\mathrm{c} \\
\mathrm{c}\end{array}$ & $\begin{array}{l}\text { Increased or decreased the amount of paid-up capital. } \\
\text { Whose headquarters moved to a new location. }\end{array}$ \\
\hline
\end{tabular}

Sources: National Archives and Record Administration. See text for details. 
Table 2

Comparing Econometric and Archival Evidence on Causes of Suspension Probit Predictions, Mississippi, 1929 and 1930

\begin{tabular}{crrrrr}
\hline & \multicolumn{2}{c}{ Predicted } & & \multicolumn{2}{r}{ Actual } \\
\cline { 2 - 3 } \cline { 5 - 6 } & $\begin{array}{r}1929 \\
(\mathrm{i})\end{array}$ & $\begin{array}{r}1930 \\
\text { (ii) }\end{array}$ & & $\begin{array}{r}1929 \\
\text { (iii) }\end{array}$ & $\begin{array}{r}1930 \\
\text { (iv) }\end{array}$ \\
\cline { 2 - 3 } $6^{\text {th }}$ District & $7.1 \%$ & $4.5 \%$ & & $7.1 \%$ & $14.2 \%$ \\
$8^{\text {th }}$ District & $3.0 \%$ & $3.0 \%$ & & $3.0 \%$ & $39.5 \%$ \\
\hline
\end{tabular}


Table 3

Categories and Causes of Permanent Bank Changes, Annual Hazard Rates, January 1929 through March 1933

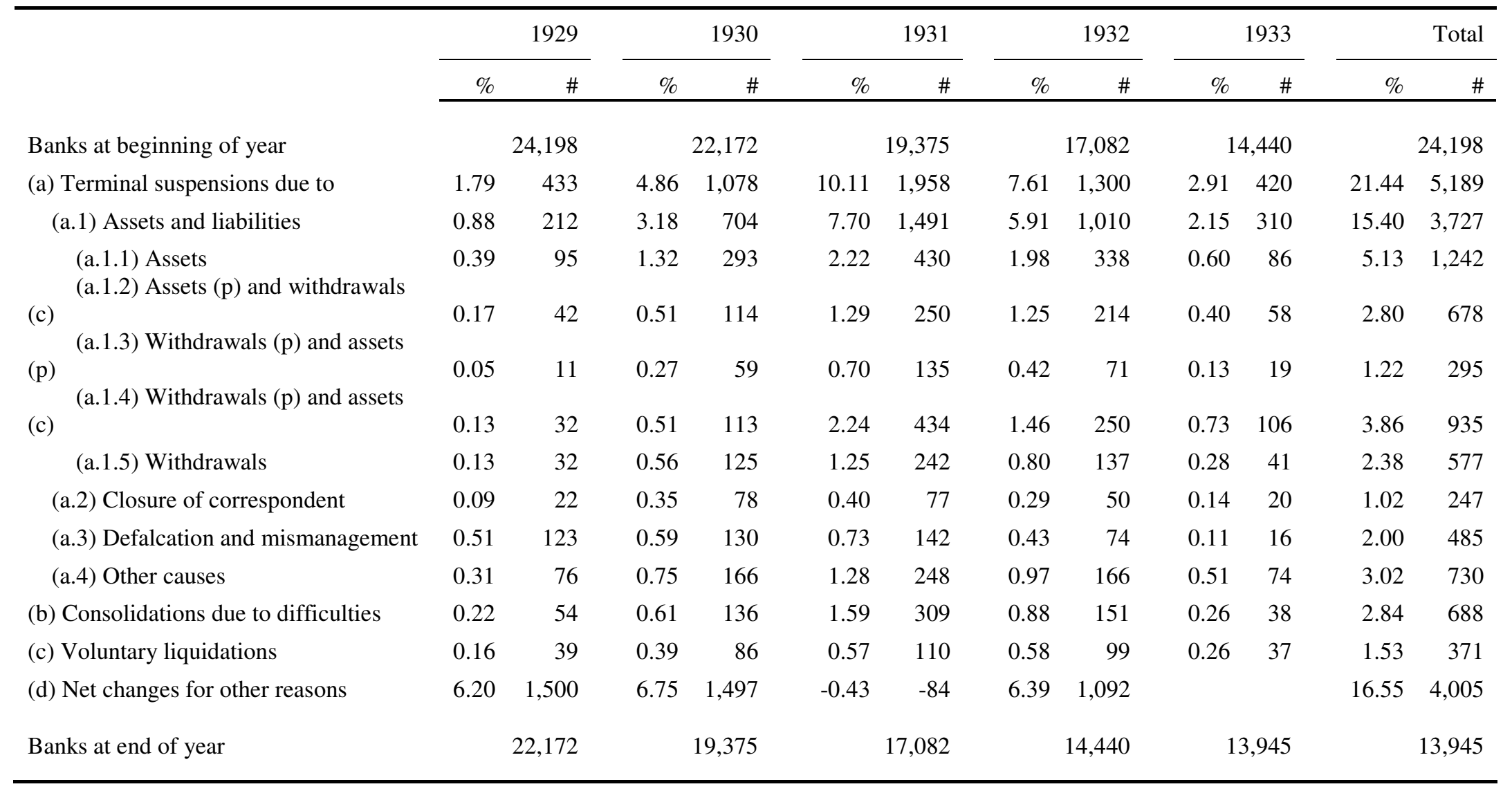

Notes: Statistics for 1933 include only the months January through March. The initial entry is the number of banks operating at the beginning of January 1929. For each year, the percentage column indicates the fraction of the banks operating in that year which experienced each event. For the total column, the percentage indicates the fraction of banks which experienced each event at some point in time from January 1929 to March 1933. (p) indicates a primary cause. (c) indicates a contributing cause.

Sources: Data on banks in operation from Wicker 1996, Table 1.1, page 2 and Federal Reserve Bulletin, September 1937, Table 
12, p. 907. Suspension data from Record Group 82, National Archives and Records Administration. 
Table 4

Causes of Temporary Bank Changes, Annual Hazard Rates, January 1929 through March 1933

\begin{tabular}{|c|c|c|c|c|c|c|c|c|c|c|c|c|}
\hline & \multicolumn{2}{|c|}{1929} & \multicolumn{2}{|c|}{1930} & \multicolumn{2}{|c|}{1931} & \multicolumn{2}{|c|}{1932} & \multicolumn{2}{|c|}{1933} & \multicolumn{2}{|c|}{ Total } \\
\hline & $\%$ & \# & $\%$ & $\#$ & $\%$ & \# & $\%$ & $\#$ & $\%$ & \# & $\%$ & $\#$ \\
\hline Banks at beginning of year & \multicolumn{2}{|c|}{24,198} & \multicolumn{2}{|c|}{22,172} & \multicolumn{2}{|c|}{19,375} & \multicolumn{2}{|c|}{17,082} & \multicolumn{2}{|c|}{14,440} & \multicolumn{2}{|c|}{24,198} \\
\hline (a) Temporary suspensions due to & 0.29 & 70 & 1.25 & 278 & 1.63 & 316 & 0.94 & 161 & 0.33 & 48 & 3.70 & 873 \\
\hline (a.1) Assets and liabilities & 0.12 & 30 & 0.65 & 144 & 1.18 & 229 & 0.67 & 114 & 0.19 & 27 & 2.31 & 544 \\
\hline (a.1.1) Assets & 0.03 & 7 & 0.10 & 23 & 0.14 & 27 & 0.09 & 16 & 0.03 & 5 & 0.33 & 78 \\
\hline (a.1.2) Assets (p) and withdrawals (c) & 0.01 & 2 & 0.13 & 28 & 0.23 & 44 & 0.20 & 35 & 0.02 & 3 & 0.47 & 112 \\
\hline (a.1.3) Withdrawals (p) and assets (p) & 0.02 & 5 & 0.05 & 12 & 0.14 & 28 & 0.02 & 3 & 0.02 & 3 & 0.22 & 51 \\
\hline (a.1.4) Withdrawals (p) and assets (c) & 0.02 & 6 & 0.14 & 32 & 0.27 & 53 & 0.26 & 44 & 0.07 & 10 & 0.61 & 145 \\
\hline (a.1.5) Withdrawals & 0.04 & 10 & 0.22 & 49 & 0.40 & 77 & 0.09 & 16 & 0.04 & 6 & 0.67 & 158 \\
\hline (a.2) Closure of correspondent & 0.02 & 6 & 0.30 & 67 & 0.10 & 20 & 0.11 & 18 & 0.03 & 4 & 0.49 & 115 \\
\hline (a.3) Defalcation and mismanagement & 0.09 & 21 & 0.11 & 24 & 0.09 & 17 & 0.01 & 2 & & & 0.27 & 64 \\
\hline (a.4) Other causes & 0.05 & 13 & 0.19 & 43 & 0.26 & 50 & 0.16 & 27 & 0.12 & 17 & 0.64 & 150 \\
\hline
\end{tabular}

Notes: Statistics for 1933 include only the months January through March. The initial entry is the number of banks operating at the beginning of January 1929. For each year, the percentage column indicates the fraction of the banks operating in that year which experienced each event. For the total column, the percentage indicates the fraction of banks which experienced each event at some point in time from January 1929 to March 1933. (p) indicates primary cause. (c) indicates contributing cause.

Sources: Data on banks in operation from Wicker 1996, Table 1.1, page 2 and Federal Reserve Bulletin, September 1937, Table 12, p. 907. Suspension data from National Archives and Records Administration, Record Group 82. See Richardson (2006) for details. 
Table 5

Number of Banks in Distress, by Category and Quarter

Winter 1929 through Winter 1933

\begin{tabular}{|c|c|c|c|c|c|c|c|}
\hline & & 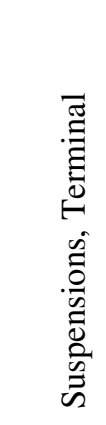 & 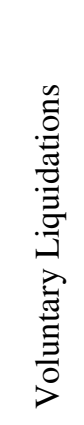 & 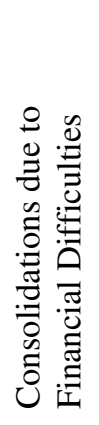 & 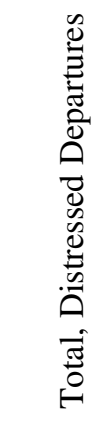 & 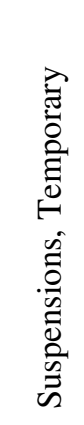 & 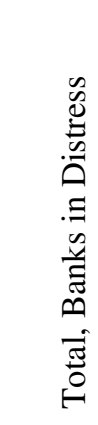 \\
\hline & & $(1)$ & (2) & (3) & (4) & $(5)$ & (6) \\
\hline \multirow[t]{4}{*}{1929} & Winter & 102 & 1 & 2 & 105 & 9 & 114 \\
\hline & Spring & 92 & 1 & 3 & 96 & 17 & 113 \\
\hline & Summer & 96 & 14 & 19 & 129 & 25 & 154 \\
\hline & Fall & 141 & 23 & 29 & 193 & 20 & 213 \\
\hline \multirow[t]{4}{*}{1930} & Winter & 229 & 30 & 38 & 297 & 32 & 329 \\
\hline & Spring & 174 & 17 & 19 & 210 & 34 & 244 \\
\hline & Summer & 185 & 19 & 15 & 219 & 21 & 240 \\
\hline & Fall & 489 & 21 & 52 & 562 & 190 & 752 \\
\hline \multirow[t]{4}{*}{1931} & Winter & 316 & 34 & 65 & 415 & 63 & 478 \\
\hline & Spring & 306 & 12 & 57 & 375 & 13 & 388 \\
\hline & Summer & 496 & 23 & 58 & 577 & 53 & 630 \\
\hline & Fall & 844 & 42 & 119 & 1,005 & 189 & 1,194 \\
\hline \multirow[t]{4}{*}{1932} & Winter & 435 & 45 & 67 & 547 & 81 & 628 \\
\hline & Spring & 282 & 20 & 36 & 338 & 23 & 361 \\
\hline & Summer & 244 & 12 & 21 & 277 & 38 & 315 \\
\hline & Fall & 340 & 22 & 25 & 387 & 21 & 408 \\
\hline 1933 & Winter & 420 & 38 & 34 & 492 & 48 & 540 \\
\hline Total & & 5,191 & 374 & 659 & 6,224 & 877 & 7,101 \\
\hline
\end{tabular}

Source: National Archives and Records Administration. 
Table 6

Deposits in Banks in Distress,

by Category and Quarter, in Thousands of Dollars

Winter 1929 through Winter 1933

\begin{tabular}{|c|c|c|c|c|c|c|c|}
\hline & & 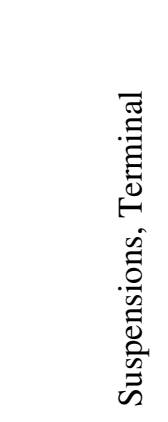 & 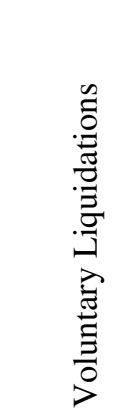 & 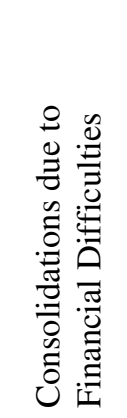 & 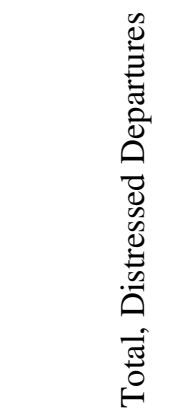 & 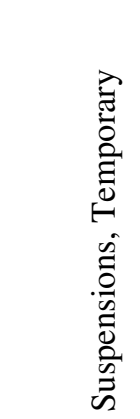 & 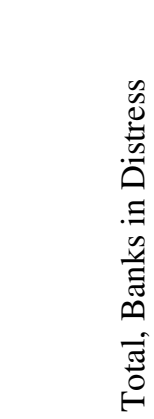 \\
\hline & & (1) & (2) & (3) & (4) & (5) & (6) \\
\hline \multirow[t]{4}{*}{1929} & Winter & 19,115 & 0 & 0 & 19,115 & 2,260 & 21,375 \\
\hline & Spring & 25,662 & 0 & 0 & 25,662 & 5,148 & 30,810 \\
\hline & Summer & 55,200 & 744 & 275 & 56,219 & 10,806 & 67,026 \\
\hline & Fall & 39,811 & 73 & 1,200 & 41,083 & 8,045 & 49,128 \\
\hline \multirow[t]{4}{*}{1930} & Winter & 75,196 & 426 & 232 & 75,854 & 12,694 & 88,547 \\
\hline & Spring & 90,169 & 91 & 17,097 & 107,356 & 14,225 & 121,581 \\
\hline & Summer & 69,145 & 44 & 23 & 69,212 & 10,315 & 79,527 \\
\hline & Fall & 524,594 & 100 & 273 & 524,968 & 89,142 & 614,109 \\
\hline \multirow[t]{4}{*}{1931} & Winter & 133,745 & 107 & 2,540 & 136,393 & 21,173 & 157,566 \\
\hline & Spring & 271,015 & 241 & 0 & 271,256 & 4,487 & 275,743 \\
\hline & Summer & 429,473 & 770 & 1,384 & 431,627 & 37,208 & 468,835 \\
\hline & Fall & 561,001 & 242 & 4,879 & 566,122 & 251,588 & 817,709 \\
\hline \multirow[t]{4}{*}{1932} & Winter & 263,645 & 0 & 842 & 264,487 & 38,536 & 303,023 \\
\hline & Spring & 199,350 & 10,737 & 0 & 210,087 & 9,259 & 219,346 \\
\hline & Summer & 83,443 & 57 & 525 & 84,025 & 16,316 & 100,340 \\
\hline & Fall & 130,903 & 0 & 331 & 131,234 & 7,699 & 138,933 \\
\hline 1933 & Winter & 191,520 & 5,050 & 510 & 197,080 & 16,156 & 213,236 \\
\hline Total & & $3,162,988$ & 18,681 & 30,111 & $3,211,780$ & 555,054 & $3,766,834$ \\
\hline
\end{tabular}

Source: National Archives and Records Administration. 
Table 7

Loans and Investments of Banks in Distress,

by Category and Quarter, in Thousands of Dollars

Winter 1929 through Winter 1933

\begin{tabular}{|c|c|c|c|c|c|c|c|}
\hline & & 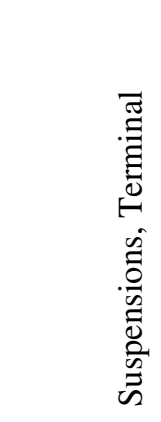 & 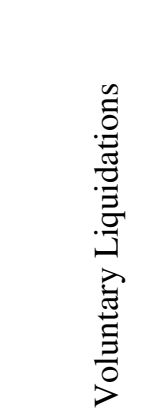 & 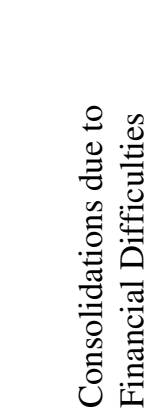 & 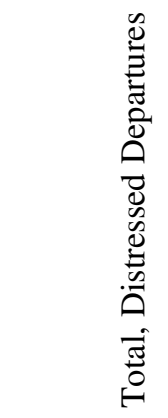 & 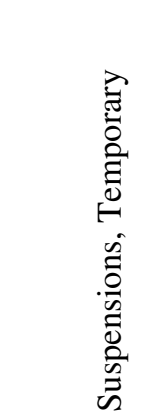 & 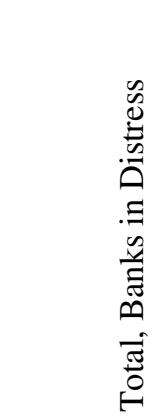 \\
\hline & & (1) & (2) & (3) & (4) & (5) & (6) \\
\hline \multirow[t]{4}{*}{1929} & Winter & 11,320 & 113 & 316 & 11,749 & 1,688 & 13,437 \\
\hline & Spring & 10,722 & 31 & 1,189 & 11,942 & 2,222 & 14,163 \\
\hline & Summer & 39,710 & 750 & 9,123 & 49,582 & 2,616 & 52,198 \\
\hline & Fall & 37,132 & 5,565 & 16,949 & 59,646 & 5,463 & 65,109 \\
\hline \multirow[t]{4}{*}{1930} & Winter & 77,680 & 3,999 & 34,862 & 116,540 & 13,217 & 129,758 \\
\hline & Spring & 92,964 & 5,415 & 24,391 & 122,770 & 15,593 & 138,363 \\
\hline & Summer & 71,922 & 2,735 & 26,790 & 101,447 & 9,723 & 111,170 \\
\hline & Fall & 557,996 & 1,793 & 55,581 & 615,370 & 99,463 & 714,833 \\
\hline \multirow{4}{*}{1931} & Winter & 147,393 & 4,678 & 53,402 & 205,473 & 22,934 & 228,407 \\
\hline & Spring & 310,684 & 3,760 & 298,349 & 612,793 & 4,788 & 617,581 \\
\hline & Summer & 495,800 & 5,619 & 95,067 & 596,485 & 40,649 & 637,135 \\
\hline & Fall & 698,744 & 6,663 & 725,454 & $1,430,860$ & 290,563 & $1,721,423$ \\
\hline \multirow[t]{4}{*}{1932} & Winter & 296,799 & 8,348 & 151,018 & 456,165 & 39,019 & 495,183 \\
\hline & Spring & 230,213 & 37,628 & 142,260 & 410,100 & 10,516 & 420,616 \\
\hline & Summer & 99,403 & 1,620 & 28,216 & 129,239 & 18,260 & 147,499 \\
\hline & Fall & 177,880 & 1,656 & 17,678 & 197,215 & 9,499 & 206,714 \\
\hline 1933 & Winter & 233,555 & 18,189 & 44,623 & 296,366 & 20,458 & 316,824 \\
\hline Total & & $3,589,915$ & 108,560 & $1,725,267$ & $5,423,742$ & 606,670 & $6,030,412$ \\
\hline
\end{tabular}

Source: National Archives and Records Administration. 
Table 8

Number of Terminal Bank Suspensions, by Cause and Quarter Winter 1929 through Winter 1933

\begin{tabular}{|c|c|c|c|c|c|c|c|c|c|c|c|}
\hline & & \multicolumn{9}{|c|}{ Cause of Terminal Suspension } & \multirow[b]{3}{*}{ 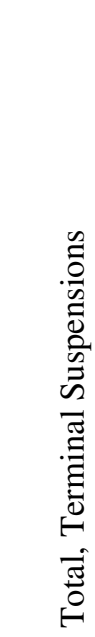 } \\
\hline & & \multicolumn{6}{|c|}{ Assets and/or Withdrawals } & \multirow[b]{2}{*}{ 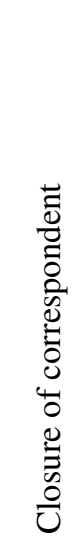 } & \multirow[b]{2}{*}{ 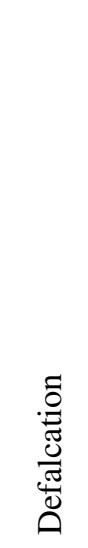 } & \multirow[b]{2}{*}{ 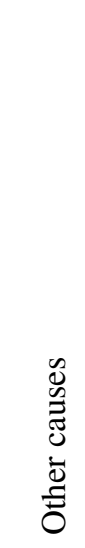 } & \\
\hline & & 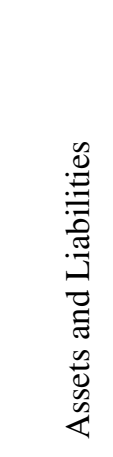 & $\begin{array}{l}\frac{n}{0} \\
\text { D. } \\
\dot{2}\end{array}$ & 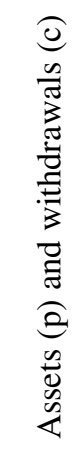 & 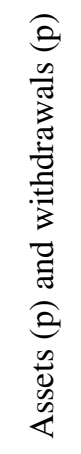 & 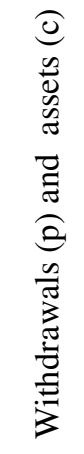 & 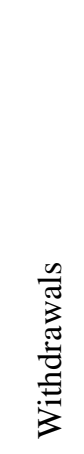 & & & & \\
\hline & & $\stackrel{\overparen{త}}{\overparen{d}}$ & 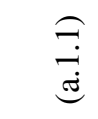 & 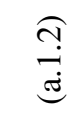 & ণְ? & 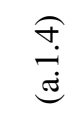 & $\frac{\sqrt[n]{n}}{\sqrt{d}}$ & ণ્త్ర & 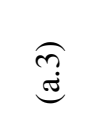 & 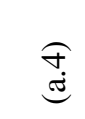 & $\circledast$ \\
\hline \multirow[t]{4}{*}{1929} & Winter & 55 & 30 & 11 & 1 & 10 & 3 & 6 & 13 & 28 & 102 \\
\hline & Spring & 56 & 30 & 11 & 1 & 9 & 5 & 1 & 7 & 28 & 92 \\
\hline & Summer & 50 & 21 & 3 & 5 & 10 & 11 & 15 & 8 & 23 & 96 \\
\hline & Fall & 96 & 44 & 19 & 10 & 8 & 15 & 3 & 12 & 30 & 141 \\
\hline \multirow[t]{4}{*}{1930} & Winter & 145 & 70 & 25 & 13 & 15 & 22 & 8 & 21 & 55 & 229 \\
\hline & Spring & 106 & 46 & 7 & 4 & 22 & 27 & 11 & 21 & 36 & 174 \\
\hline & Summer & 133 & 68 & 12 & 11 & 17 & 25 & 3 & 17 & 32 & 185 \\
\hline & Fall & 327 & 109 & 77 & 31 & 59 & 51 & 58 & 21 & 83 & 489 \\
\hline \multirow[t]{4}{*}{1931} & Winter & 258 & 94 & 53 & 23 & 36 & 52 & 3 & 14 & 41 & 316 \\
\hline & Spring & 240 & 66 & 21 & 25 & 102 & 26 & 5 & 15 & 46 & 306 \\
\hline & Summer & 346 & 134 & 61 & 30 & 65 & 56 & 34 & 18 & 98 & 496 \\
\hline & Fall & 651 & 150 & 111 & 51 & 238 & 101 & 42 & 24 & 127 & 844 \\
\hline \multirow[t]{4}{*}{1932} & Winter & 341 & 91 & 46 & 27 & 108 & 69 & 17 & 17 & 60 & 435 \\
\hline & Spring & 227 & 82 & 41 & 15 & 57 & 32 & 7 & 13 & 35 & 282 \\
\hline & Summer & 197 & 70 & 49 & 15 & 40 & 23 & 5 & 5 & 37 & 244 \\
\hline & Fall & 248 & 86 & 85 & 15 & 49 & 13 & 21 & 11 & 60 & 340 \\
\hline 1933 & Winter & 304 & 83 & 53 & 20 & 107 & 41 & 21 & 5 & 90 & 420 \\
\hline Total & & 3,780 & 1,274 & 685 & 297 & 952 & 572 & 260 & 242 & 909 & 5,191 \\
\hline
\end{tabular}

Source: National Archives and Records Administration. 
Table 9

Deposits in Terminal Bank Suspensions,

by Cause and Quarter, in Millions of Dollars

Winter 1929 through Winter 1933

Cause of Terminal Suspension

Assets and/or Withdrawals

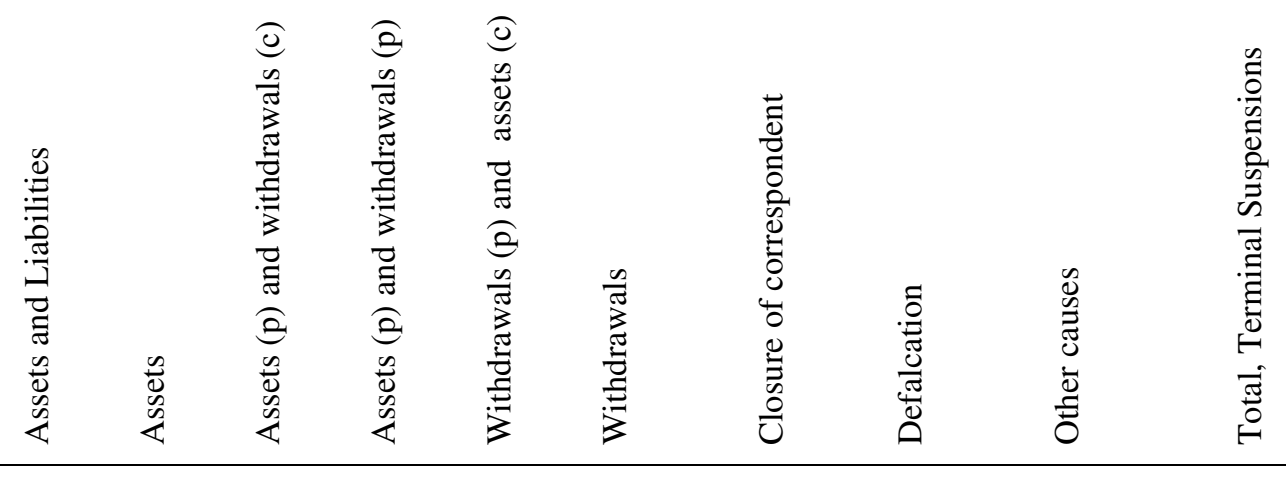

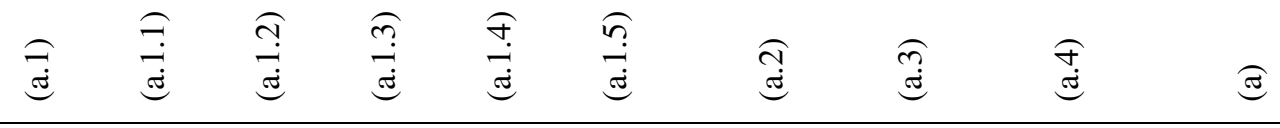

$\begin{array}{llllllllllll}1929 & \text { Winter } & 8.2 & 3.6 & 1.3 & 0.1 & 2.9 & 0.2 & 0.8 & 2.8 & 7.3 & 19.1\end{array}$

$\begin{array}{lllllllllll}\text { Spring } & 16.4 & 4.8 & 1.8 & 0.0 & 9.2 & 0.5 & 2.1 & 1.7 & 5.6 & 25.7\end{array}$

$\begin{array}{lllllllllll}\text { Summer } & 18.9 & 5.9 & 1.1 & 2.6 & 7.2 & 2.1 & 24.5 & 1.5 & 10.4 & 55.2\end{array}$

$\begin{array}{lllllllllll}\text { Fall } & 29.1 & 9.5 & 10.5 & 2.5 & 3.0 & 3.6 & 0.4 & 2.4 & 8.0 & 39.8\end{array}$

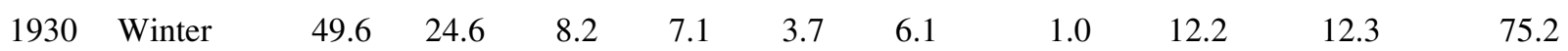

$\begin{array}{lllllllllll}\text { Spring } & 67.8 & 24.4 & 22.1 & 1.8 & 7.8 & 11.6 & 6.5 & 5.7 & 10.2 & 90.2\end{array}$

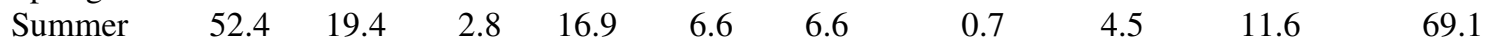

$\begin{array}{lllllllllll}\text { Fall } & 461.8 & 51.7 & 246.9 & 13.1 & 76.5 & 73.7 & 16.7 & 5.7 & 40.5 & 524.6\end{array}$

$\begin{array}{llllllllllll}1931 & \text { Winter } & 109.5 & 32.3 & 22.8 & 16.1 & 19.8 & 18.5 & 5.1 & 6.0 & 13.1 & 133.7\end{array}$

$\begin{array}{lllllllllll}\text { Spring } & 236.3 & 24.7 & 10.4 & 27.9 & 133.8 & 39.5 & 1.3 & 3.3 & 30.1 & 271.0\end{array}$

$\begin{array}{lrrrrrrrrrr}\text { Summer } & 306.9 & 35.2 & 60.0 & 31.7 & 106.6 & 73.4 & 17.3 & 10.7 & 94.7 & 429.5\end{array}$

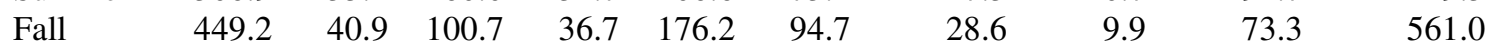

$\begin{array}{llllllllllll}1932 & \text { Winter } & 187.7 & 44.9 & 21.7 & 14.2 & 61.1 & 45.9 & 4.3 & 4.4 & 67.2 & 263.6\end{array}$

$\begin{array}{lllllllllll}\text { Spring } & 184.1 & 40.0 & 24.8 & 2.1 & 93.1 & 24.1 & 1.4 & 3.3 & 10.5 & 199.4\end{array}$

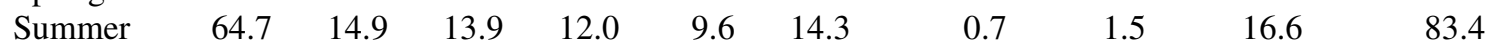

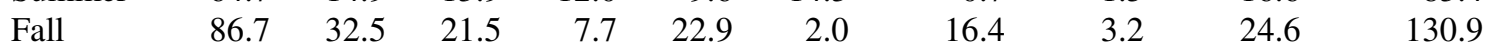

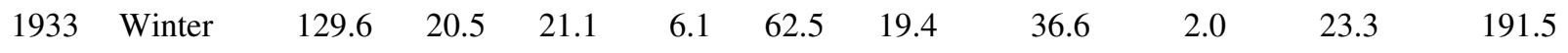

$\begin{array}{lllllllllll}\text { Total } & 2,458.8 & 429.8 & 591.6 & 198.8 & 802.5 & 436.2 & 164.2 & 80.7 & 459.2 & 3,163.0\end{array}$

Source: National Archives and Records Administration. 
Table 10

Loans and Investments in Terminal Bank Suspensions,

by Cause and Quarter, in Millions of Dollars

Winter 1929 through Winter 1933

Cause of Terminal Suspension

Assets and/or Withdrawals

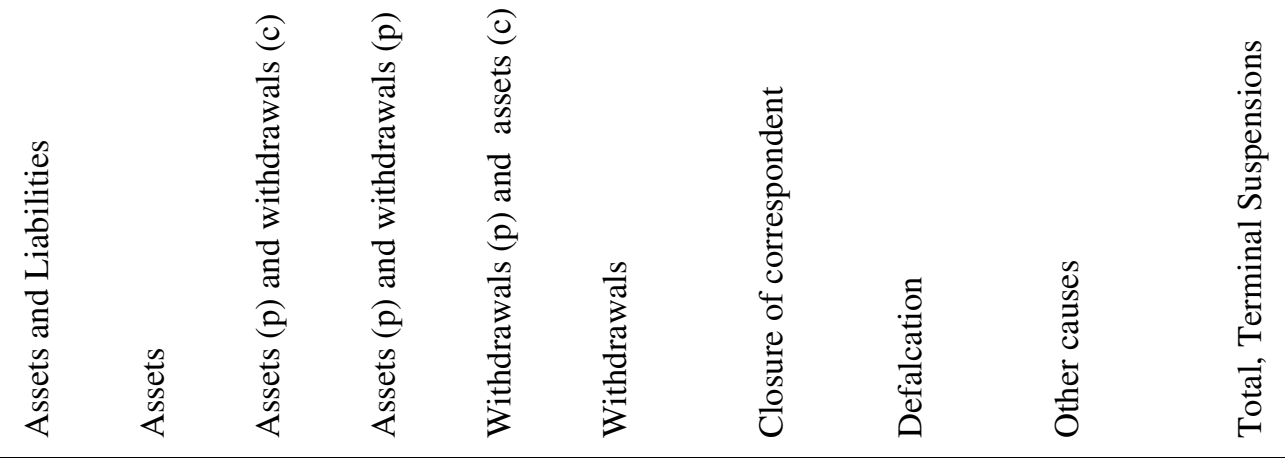

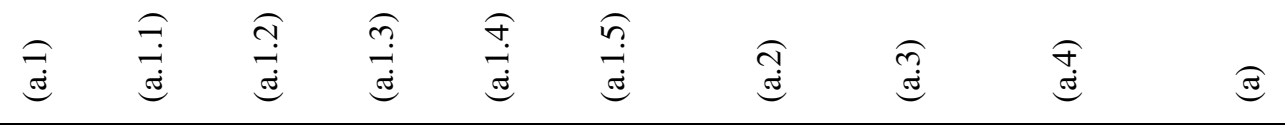

$\begin{array}{llllllllllll}1929 & \text { Winter } & 6.3 & 2.9 & 1.0 & 0.0 & 2.1 & 0.2 & 0.8 & 1.6 & 2.6 & 11.3\end{array}$

$\begin{array}{lllllllllll}\text { Spring } & 5.7 & 3.3 & 0.9 & 0.4 & 0.6 & 0.4 & 2.0 & 0.6 & 2.5 & 10.7\end{array}$

$\begin{array}{lllllllllll}\text { Summer } & 13.3 & 9.3 & 1.1 & 1.7 & 0.3 & 1.0 & 18.1 & 1.3 & 7.1 & 39.7\end{array}$

$\begin{array}{lllllllllll}\text { Fall } & 29.3 & 8.8 & 12.0 & 1.2 & 3.7 & 3.6 & 0.4 & 0.9 & 6.5 & 37.1\end{array}$

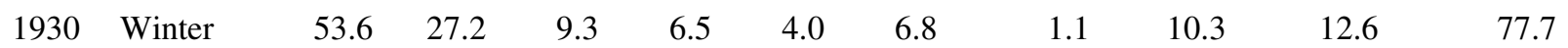

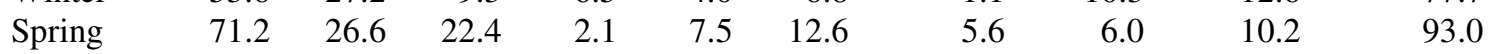

$\begin{array}{lrrrrrrrrrr}\text { Summer } & 55.5 & 19.2 & 3.4 & 17.8 & 7.8 & 7.3 & 0.3 & 4.5 & 11.6 & 71.9\end{array}$

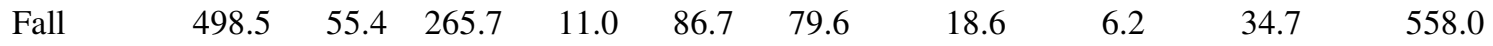

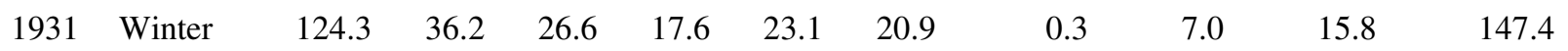

$\begin{array}{lllllllllll}\text { Spring } & 265.9 & 28.7 & 10.6 & 30.4 & 153.8 & 42.3 & 1.6 & 3.5 & 39.6 & 310.7\end{array}$

$\begin{array}{lrrrrrrrrrr}\text { Summer } & 361.8 & 54.2 & 75.5 & 34.5 & 118.3 & 79.2 & 19.1 & 11.8 & 103.1 & 495.8\end{array}$

$\begin{array}{lllllllllll}\text { Fall } & 573.0 & 50.3 & 113.1 & 42.1 & 258.7 & 108.9 & 29.4 & 10.9 & 85.5 & 698.7\end{array}$

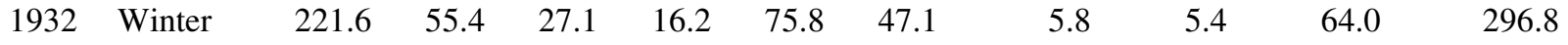

$\begin{array}{lrlllllllll}\text { Spring } & 211.6 & 45.8 & 29.6 & 3.7 & 105.5 & 27.0 & 1.5 & 4.2 & 12.9 & 230.2\end{array}$

$\begin{array}{lrrrrrrrrrr}\text { Summer } & 77.6 & 16.2 & 16.9 & 15.3 & 13.7 & 15.5 & 0.8 & 2.0 & 19.0 & 99.4\end{array}$

$\begin{array}{lllllllllll}\text { Fall } & 122.8 & 47.8 & 28.6 & 12.5 & 31.6 & 2.3 & 18.1 & 3.4 & 33.6 & 177.9\end{array}$

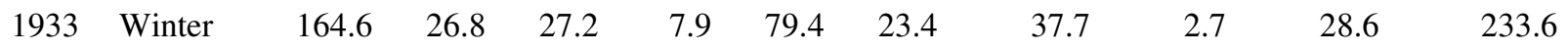

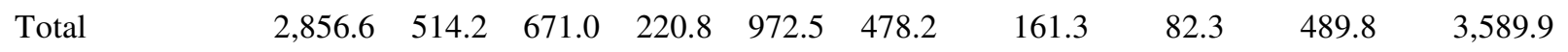

Source: National Archives and Records Administration. 
Table 11

Number of Temporary Bank Suspensions,

by Cause and Quarter, in Thousands of Dollars

Winter 1929 through Winter 1933

\begin{tabular}{|c|c|c|c|c|c|c|c|c|c|c|c|}
\hline & & \multicolumn{9}{|c|}{ Cause of Temporary Suspension } & \multirow[b]{3}{*}{ 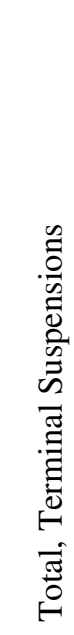 } \\
\hline & & \multicolumn{6}{|c|}{ Assets and/or Withdrawals } & \multirow[b]{2}{*}{ 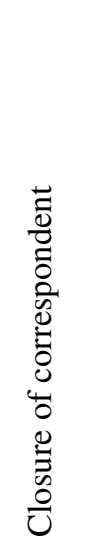 } & \multirow[b]{2}{*}{ 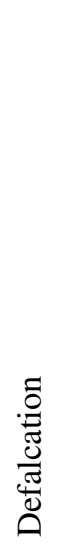 } & \multirow[b]{2}{*}{ 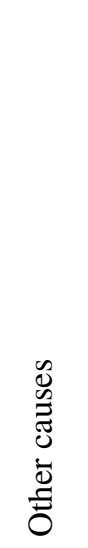 } & \\
\hline & & 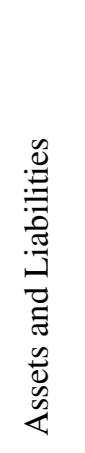 & $\begin{array}{l}0 \\
0 \\
0 \\
0 \\
0\end{array}$ & 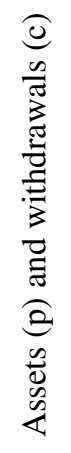 & 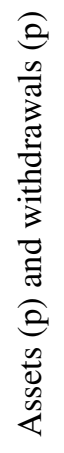 & 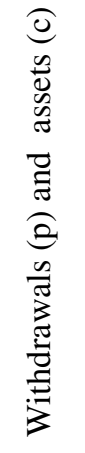 & 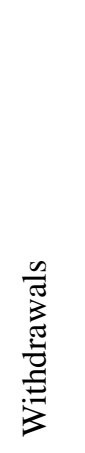 & & & & \\
\hline & & $\widehat{\overparen{d}}$ & 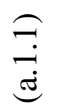 & $\frac{\overparen{\overbrace{}}}{\stackrel{\Xi}{d}}$ & $\frac{\overparen{?}}{\mathfrak{g}}$ & 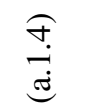 & $\frac{\widetilde{n}}{\mathfrak{త}}$ & $\underset{\overbrace ָ}{\overparen{త}}$ & $\stackrel{\overbrace{}]}{\overparen{d}}$ & 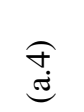 & త్రీ \\
\hline \multirow[t]{4}{*}{1929} & Winter & 3 & 2 & 0 & 0 & 0 & 1 & 0 & 1 & 5 & 9 \\
\hline & Spring & 6 & 3 & 0 & 1 & 0 & 2 & 0 & 2 & 9 & 17 \\
\hline & Summer & 11 & 4 & 0 & 0 & 4 & 3 & 6 & 2 & 6 & 25 \\
\hline & Fall & 13 & 1 & 2 & 4 & 3 & 3 & 0 & 1 & 6 & 20 \\
\hline \multirow[t]{4}{*}{1930} & Winter & 20 & 6 & 0 & 5 & 3 & 6 & 4 & 0 & 8 & 32 \\
\hline & Spring & 20 & 4 & 1 & 1 & 9 & 5 & 4 & 6 & 4 & 34 \\
\hline & Summer & 14 & 4 & 1 & 0 & 5 & 4 & 0 & 2 & 5 & 21 \\
\hline & Fall & 84 & 7 & 25 & 3 & 17 & 32 & 59 & 4 & 43 & 190 \\
\hline \multirow[t]{4}{*}{1931} & Winter & 45 & 6 & 10 & 3 & 6 & 20 & 3 & 4 & 11 & 63 \\
\hline & Spring & 11 & 3 & 1 & 2 & 3 & 2 & 0 & 0 & 2 & 13 \\
\hline & Summer & 38 & 4 & 9 & 4 & 6 & 15 & 3 & 0 & 12 & 53 \\
\hline & Fall & 138 & 18 & 23 & 18 & 40 & 39 & 14 & 1 & 36 & 189 \\
\hline \multirow[t]{4}{*}{1932} & Winter & 61 & 7 & 12 & 3 & 26 & 13 & 5 & 0 & 15 & 81 \\
\hline & Spring & 18 & 3 & 8 & 0 & 5 & 2 & 1 & 0 & 4 & 23 \\
\hline & Summer & 21 & 4 & 10 & 0 & 6 & 1 & 9 & 0 & 8 & 38 \\
\hline & Fall & 14 & 2 & 5 & 1 & 6 & 0 & 3 & 0 & 4 & 21 \\
\hline 1933 & Winter & 27 & 5 & 3 & 3 & 10 & 6 & 4 & 0 & 17 & 48 \\
\hline Total & & 544 & 83 & 110 & 48 & 149 & 154 & 115 & 23 & 193 & 877 \\
\hline
\end{tabular}

Source: National Archives and Records Administration. 
Table 12

Deposits in Temporary Bank Suspensions, by Cause and Quarter Winter 1929 through Winter 1933

\begin{tabular}{|c|c|c|c|c|c|c|c|c|c|c|c|}
\hline & & \multicolumn{9}{|c|}{ Cause of Temporary Suspension } & \multirow[b]{3}{*}{ 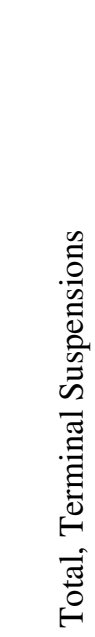 } \\
\hline & & \multicolumn{6}{|c|}{ Assets and/or Withdrawals } & \multirow[b]{2}{*}{ 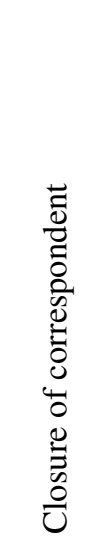 } & \multirow[b]{2}{*}{ 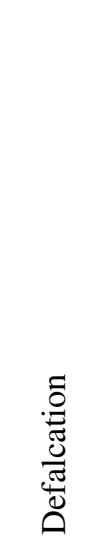 } & \multirow[b]{2}{*}{ 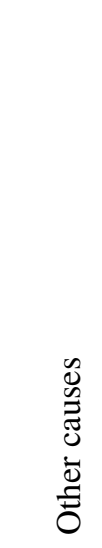 } & \\
\hline & & 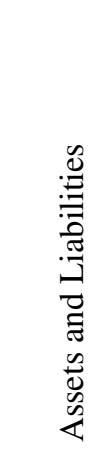 & $\begin{array}{l}\frac{n}{0} \\
\text { 定 } \\
0\end{array}$ & 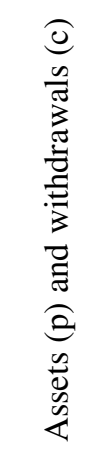 & 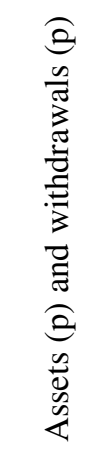 & 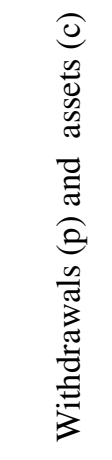 & 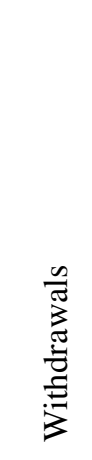 & & & & \\
\hline & & $\stackrel{\overparen{d}}{\overparen{d}}$ & ב্] & ণִ & $\stackrel{\overbrace{}]}{\overparen{త}}$ & 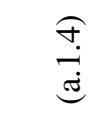 & $\frac{\sqrt[n]{n}}{\mathfrak{\Xi}}$ & 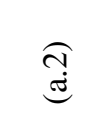 & ָై & 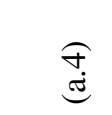 & Ð્త \\
\hline \multirow[t]{4}{*}{1929} & Winter & 0.9 & 0.4 & 0.0 & 0.0 & 0.0 & 0.5 & 0.0 & 0.2 & 1.2 & 2.3 \\
\hline & Spring & 2.5 & 2.1 & 0.0 & 0.3 & 0.0 & 0.1 & 0.0 & 0.3 & 2.4 & 5.1 \\
\hline & Summer & 5.8 & 2.4 & 0.0 & 0.0 & 1.9 & 1.5 & 2.4 & 0.5 & 2.1 & 10.8 \\
\hline & Fall & 5.4 & 0.2 & 2.0 & 1.3 & 1.3 & 0.5 & 0.0 & 0.2 & 2.5 & 8.0 \\
\hline \multirow[t]{4}{*}{1930} & Winter & 8.8 & 1.1 & 0.0 & 1.6 & 0.5 & 5.6 & 0.8 & 0.0 & 3.1 & 12.7 \\
\hline & Spring & 8.1 & 0.8 & 0.4 & 0.9 & 3.8 & 2.2 & 1.0 & 3.0 & 2.2 & 14.2 \\
\hline & Summer & 6.7 & 1.2 & 0.1 & 0.0 & 1.4 & 4.0 & 0.0 & 0.8 & 2.8 & 10.3 \\
\hline & Fall & 37.1 & 1.4 & 7.9 & 0.7 & 8.5 & 18.7 & 15.2 & 5.6 & 31.2 & 89.1 \\
\hline \multirow[t]{4}{*}{1931} & Winter & 14.9 & 2.9 & 1.7 & 0.8 & 3.6 & 5.9 & 0.6 & 1.3 & 4.3 & 21.2 \\
\hline & Spring & 3.8 & 0.4 & 0.5 & 1.2 & 0.7 & 1.0 & 0.0 & 0.0 & 0.7 & 4.5 \\
\hline & Summer & 30.3 & 1.6 & 3.5 & 3.4 & 10.5 & 11.3 & 1.8 & 0.0 & 5.0 & 37.2 \\
\hline & Fall & 147.2 & 13.9 & 26.1 & 37.1 & 41.6 & 28.4 & 38.8 & 0.3 & 65.3 & 251.6 \\
\hline \multirow{4}{*}{1932} & Winter & 30.3 & 2.6 & 8.4 & 0.6 & 13.5 & 5.2 & 3.7 & 0.0 & 4.5 & 38.5 \\
\hline & Spring & 7.9 & 0.4 & 4.4 & 0.0 & 2.7 & 0.3 & 0.0 & 0.0 & 1.3 & 9.3 \\
\hline & Summer & 10.6 & 1.6 & 2.6 & 0.0 & 6.2 & 0.3 & 3.8 & 0.0 & 2.0 & 16.3 \\
\hline & Fall & 4.9 & 0.2 & 2.0 & 0.1 & 2.5 & 0.0 & 2.0 & 0.0 & 0.7 & 7.7 \\
\hline 1933 & Winter & 11.5 & 1.2 & 1.9 & 0.8 & 2.5 & 5.2 & 0.6 & 0.0 & 4.0 & 16.2 \\
\hline Total & & 336.7 & 34.2 & 61.5 & 48.9 & 101.3 & 90.7 & 70.8 & 12.1 & 135.4 & 555.1 \\
\hline
\end{tabular}

Source: National Archives and Records Administration. 
Table 13

Loans and Investments in Temporary Bank Suspensions, by Cause and Quarter Winter 1929 through Winter 1933

\begin{tabular}{|c|c|c|c|c|c|c|c|c|c|c|c|}
\hline & & \multicolumn{9}{|c|}{ Cause of Temporary Suspension } & \multirow[b]{3}{*}{ 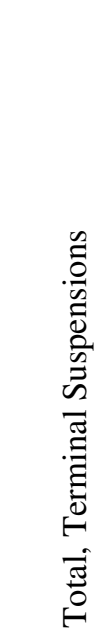 } \\
\hline & & \multicolumn{6}{|c|}{ Assets and/or Withdrawals } & \multirow[b]{2}{*}{ 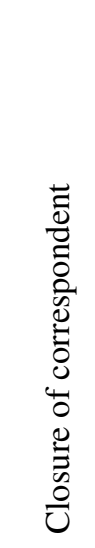 } & \multirow[b]{2}{*}{ 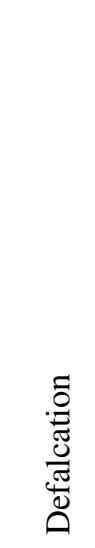 } & \multirow[b]{2}{*}{ 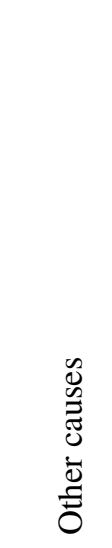 } & \\
\hline & & 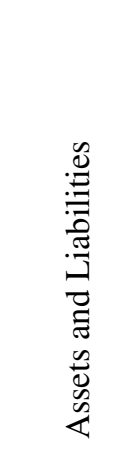 & $\begin{array}{l}\frac{n}{0} \\
\tilde{W} \\
\tilde{\psi}\end{array}$ & 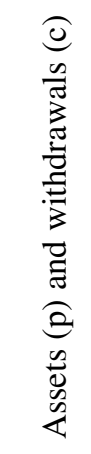 & 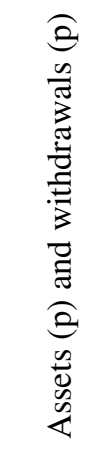 & 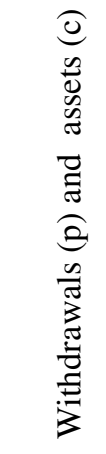 & 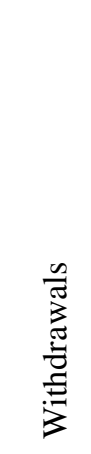 & & & & \\
\hline & & $\underset{\overparen{J}}{\overparen{\Xi}}$ & 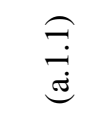 & ণ্] & ণ? & 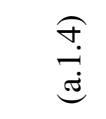 & 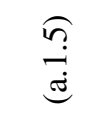 & ત્త & $\stackrel{\overbrace{}}{\overparen{d}}$ & 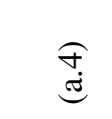 & ङ \\
\hline \multirow[t]{4}{*}{1929} & Winter & 0.6 & 0.0 & 0.0 & 0.0 & 0.0 & 0.5 & 0.0 & 0.1 & 1.0 & 1.7 \\
\hline & Spring & 1.6 & 1.0 & 0.0 & 0.0 & 0.0 & 0.5 & 0.0 & 0.3 & 0.3 & 2.2 \\
\hline & Summer & 1.5 & 0.7 & 0.0 & 0.0 & 0.7 & 0.0 & 0.0 & 0.3 & 0.9 & 2.6 \\
\hline & Fall & 4.6 & 0.0 & 1.9 & 1.2 & 0.9 & 0.5 & 0.0 & 0.1 & 0.7 & 5.5 \\
\hline \multirow[t]{4}{*}{1930} & Winter & 9.2 & 1.1 & 0.0 & 1.8 & 0.7 & 5.7 & 0.7 & 0.0 & 3.3 & 13.2 \\
\hline & Spring & 9.2 & 1.0 & 0.5 & 0.9 & 4.4 & 2.4 & 0.9 & 3.2 & 2.3 & 15.6 \\
\hline & Summer & 6.1 & 0.9 & 0.1 & 0.0 & 1.6 & 3.4 & 0.0 & 0.9 & 2.7 & 9.7 \\
\hline & Fall & 39.8 & 2.0 & 9.5 & 0.8 & 9.8 & 17.7 & 15.4 & 5.0 & 39.2 & 99.5 \\
\hline \multirow[t]{4}{*}{1931} & Winter & 16.9 & 3.0 & 2.0 & 0.8 & 4.0 & 7.1 & 0.5 & 1.3 & 4.2 & 22.9 \\
\hline & Spring & 4.1 & 0.5 & 0.6 & 1.2 & 0.7 & 1.1 & 0.0 & 0.0 & 0.7 & 4.8 \\
\hline & Summer & 33.6 & 1.6 & 3.8 & 3.9 & 11.9 & 12.4 & 1.8 & 0.0 & 5.2 & 40.6 \\
\hline & Fall & 162.5 & 10.5 & 30.6 & 42.7 & 49.0 & 29.6 & 42.1 & 0.3 & 85.6 & 290.6 \\
\hline \multirow[t]{4}{*}{1932} & Winter & 30.2 & 2.9 & 4.4 & 0.7 & 16.7 & 5.6 & 4.2 & 0.0 & 4.6 & 39.0 \\
\hline & Spring & 9.1 & 0.4 & 4.8 & 0.0 & 3.5 & 0.3 & 0.1 & 0.0 & 1.4 & 10.5 \\
\hline & Summer & 11.4 & 1.8 & 2.9 & 0.0 & 6.4 & 0.3 & 4.1 & 0.0 & 2.8 & 18.3 \\
\hline & Fall & 6.0 & 0.3 & 2.7 & 0.2 & 2.8 & 0.0 & 2.2 & 0.0 & 1.4 & 9.5 \\
\hline 1933 & Winter & 16.3 & 1.5 & 2.0 & 1.0 & 3.2 & 8.6 & 0.6 & 0.0 & 3.5 & 20.5 \\
\hline Total & & 362.6 & 29.1 & 66.0 & 55.3 & 116.4 & 95.9 & 72.5 & 11.7 & 159.9 & 606.7 \\
\hline
\end{tabular}

Source: National Archives and Records Administration. 


\section{Appendix: The St. 6386 Forms.}

F. R. Board

Form St. 6386a

November 1929

\section{BANK CONSOLIDATIONS}

(Include absorptions, mergers, etc.)

Effective data of consolidation

Federal Reserve District

\begin{tabular}{c|c|c|c|c|}
\hline Name and Location of Banks & $\begin{array}{c}\text { Member } \\
\text { or } \\
\text { nonmember }\end{array}$ & Capital & $\begin{array}{c}\text { Surplus } \\
\text { and } \\
\text { profits }\end{array}$ & $\begin{array}{c}\text { Loans } \\
\text { and } \\
\text { investments }\end{array}$ \\
\hline
\end{tabular}

(a) Banks entering into consolidation:

(b) New or consolidated bank:

Is the consolidated institution a newly chartered bank? If not, give the name of the bank (before consolidation) under whose charter the consolidated institution is to operate:

Give the names of banks, if any, that were in financial difficulties at time of consolidation:

Disposition made of the head office of each bank entering into consolidation:

Did any of the banks entering into consolidation have branches?

Were any of the banks affiliated with banking groups or chains?

(Report details on Forms St. 6386d and St. 6386e)

Terms of consolidation, if known, etc. 
F. R. Board

Form St. 6386b

November 1929

Date of suspension

Name and location of bank

\section{Loans and}

Capital \$
BANK SUSPENSIONS

Federal Reserve District

Member or nonmember
Gross Deposits \$

Borrowings from Federal Reserve Bank \$ From other banks $\$$

Condition figures are as of

Closing directed by

Causes of suspension: Check in the appropriate column those of the following which apply, either as primary or contributing causes, amplifying the indicated causes with such supplementary data as may be available.

1. Slow, Doubtful or worthless paper

\begin{tabular}{|l|l|}
\hline Primary cause & Secondary cause \\
\hline
\end{tabular}

2. Failure of banking correspondent (Name of failed correspondent)

3. Failure of other large debtor

(Name of failed debtor and connection with bank, if any)

4. Defalcation

5. Heavy withdrawals

6. Other causes (specify) )

\begin{tabular}{l|l|l|}
\hline & & \\
\hline
\end{tabular}

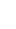

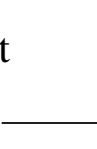


F. R. Board

Form St. 6386c

Nov. 1929
ORGANIZATIONS, LIQUIDATIONS, CONVERSIONS, AND OTHER CHANGES IN STATUS OF MEMBER AND NONMEMBER BANKS

Effective date of change

Federal Reserve District

Character of change

Name and location of

bank before change

Member or

nonmember

Name and location of

Member or

bank after change

Surplus

Capital \$ and profits $\$$ nonmember

Loans and investments \$

Condition figures are as of

Is the above change in status final or merely preliminary to a further change, and if preliminary, what further change is contemplated?

Is the case of conversions and successions, were financial difficulties responsible to any extent for the change in status?

Remarks:

(In the case of suspended banks reopened for business, give the change in capital account, the assessment paid by stockholders, etc.) 


\section{Bibliography}

Bernanke, B. S. "Nonmonetary Effects of the Financial Crisis in the Propagation of the Great Depression.” American Economic Review, June 1983, (73), pp. 257-276.

Board of Governors of the Federal Reserve System. 1929. "Memorandum Regarding Preparation of Reports of Changes in Status of Member and Nonmember Banks," Memo: November 18, 1929. National Archives, Record Group 82, Federal Reserve Central Subject File, 421.113.

---- 1930. Committee on Branch, Group and Chain Banking, "Bank Changes - Definitions of Terms," Memo: November 5, 1930. National Archives, Record Group 82, Federal Reserve Central Subject File, 421.113-1.

---- 1931. Committee on Branch, Group and Chain Banking. "Comments Regarding Preparation of Form F." 23 November 1931. National Archives, Record Group 82, Federal Reserve Central Subject File, 421.113-1, Forms and Instructions.

---- $\quad$ 1937. "Bank Suspensions in the United States." Federal Reserve Bulletin. Washington, D.C.: Board of Governors of the Federal Reserve System. September, 1937.

----- Banking and Monetary Statistics, 1914-1941. Washington, D.C.: Federal Reserve System, 1943.

----- All Bank Statistics, 1896-1955. Washington, D.C.: Federal Reserve System, 1959.

Calomiris, Charles W. and Joseph R. Mason. "Contagion and Bank Failures During The Great Depression: The June 1932 Chicago Banking Panic.” American Economic Review, December 1997, 87(5), pp. 863-883.

----- "Fundamentals, Panics, and Bank Distress During the Depression." American Economic Review, December 2003, 93(5): pp. 1615-1646.

Carlson, Mark. “Are Branch Banks Better Survivors? Evidence from the Depression Era." Economic Inquiry, January 2004, (42), pp. 111-126

Eichengreen, Barry. Golden Fetters. New York: Oxford University Press, 1992.

Friedman, Milton and Schwartz, Anna J. 1963. A Monetary History of the United States, 1867-1960. Princeton: Princeton University Press.

Goldenweiser, E. A., et al. 1931. Bank Suspensions in the United States, 1892-1931. Volume 4. Material prepared for the information of the Federal Reserve System by the Federal Reserve Committee on Branch, Group, and Chain Banking.

Hamilton, David. "The Causes of the Banking Panic of 1930, Another View.” Journal of Southern History November 1985, (51), pp. 581-608.

Kennedy, Susan Estabrook. The Banking Crisis of 1933. Lexington, KY: University Press of Kentucky, 1973.

Lucia, Joseph. 1985. "The Failure of the Bank of the United States: A Reappraisal.” Explorations in Economic History 22 (October): 402-16. 
McFerrin, James B. 1939. Caldwell and Company. Chapel Hill: University of North Carolina Press.

Meltzer, Allan H. "Monetary and Other Explanations for the Start of the Great Depression." Journal of Monetary Economics 2 (1976): 455-72.

----- A History of the Federal Reserve, Volume 1, 1913-1951. Chicago: University of Chicago Press, 2003.

Mitchener, Kris James. 2004. Bank Supervision, Regulation, and Instability during the Great Depression. NBER Working Paper 10475. May 2004.

Gary Richardson. "The Records of the Federal Reserve Board of Governors in the National Archives of the United States." Financial History Review (forthcoming June 2006).

Richardson, Gary and William Troost. "Monetary Intervention Mitigated Banking Panics During the Great Depression: Quasi-Experimental Evidence from the Federal Reserve Border in Mississippi, 1929 to 1933..” UC Irvine Mimeo, 2005.

Romer, Christina. "The Nation in Depression.” The Journal of Economic Perspectives. Vol 7, No. 2 (Spring, 1993), pp. 19-39.

Temin, Peter. Did Monetary Forces Cause the Great Depression? New York: W.W. Norton, 1976.

---- Lessons from the Great Depression. Cambridge, MA: MIT Press, 1989.

United States, Bureau of the Census. Historical statistics of the United States, colonial times to 1970. Bicentennial Edition. Washington: U.S. Dept. of Commerce, U.S. Govt. Print. Off., 1975

Wheelock, David. "Member Bank Borrowing and the Fed's Contractionary Monetary Policy During the Great Depression." Journal of Money, Credit and Banking November 1990, (22) pp. 409-426.

White, Eugene. 1984. “A Reinterpretation of the Banking Crisis of 1930.” Journal of Economic History 44 (March): 119-38.

Wicker, Elmus. 1980. “A Reconsideration of the Causes of the Banking Panic of 1930." Journal of Economic History 40 (September): 571-83.

----- 1996. The Banking Panics of the Great Depression. Cambridge: Cambridge University Press, 1996.

Young, R. A. "Memorandum Regarding Preparation of Reports of Changes in Status of Member and Nonmember Banks.” Memo: November 18, 1929. National Archives, Record Group 82, Federal Reserve Central Subject File, 421.3, Group and Chain Banking (1924-1929). 